HIAS-E-86

\title{
Nonlinear Effects of Population Aging on Economic Growth?
}

\author{
Hyun-Hoon Lee ${ }^{(a)}$ and Kwanho Shin ${ }^{(b),(c)}$ \\ (a) Kangwon National University, Republic of Korea \\ (b) Korea University, Republic of Korea \\ (c) Hitotsubashi Institute for Advanced Study, Hitotsubashi University
}

April, 2019

2-1, Naka, Kunitachi, Tokyo 186-8601, Japan

tel:+81 425808604 http://hias.ad.hit-u.ac.jp/

HIAS discussion papers can be downloaded without charge from: http://hdl.handle.net/10086/27202

https://ideas.repec.org/s/hit/hiasdp.html

All rights reserved. 


\title{
Nonlinear Effects of Population Aging on Economic Growth?+
}

\author{
April 2019 \\ Hyun-Hoon Lee \\ (Kangwon National University, Republic of Korea) \\ Kwanho $\operatorname{Shin}^{++}$ \\ (Korea University, Republic of Korea \& Hitotsubashi Institute for Advanced Study, \\ Hitotsubashi University)
}

\begin{abstract}
$\underline{\text { Abstract }}$
Using panel data for 142 countries for the period from 1960 to 2014, we assess the effects of population aging on economic growth. We find that population aging proxied by old-age population share (or old-age dependency ratio) negatively affects economic growth only when it reaches a certain high level and its negative effects grow stronger as population aging deepens. We also find that population aging has hampered economic growth during more recent years, especially in more aged countries which are mostly developed countries. This nonlinear effect of aging is mainly driven by the fact that we use old-age population share as a proxy for aging. If we use lower working-age population share as a proxy for aging, the nonlinear relationship disappears: working-age population share is positively related to economic growth in a linear way.
\end{abstract}

Keywords:

Population aging, working-age population, economic growth, nonlinearity, developed countries

JEL codes:

$\mathrm{J} 11, \mathrm{O} 47, \mathrm{O} 57$

\footnotetext{
${ }^{+}$Presented at the $14^{\text {th }}$ Annual Conference of Asia-Pacific Economic Association, University of Sothern California, USA, August 3-4 and at the 15th Korea and the World Economy Conference, Jeju, Republic of Korea, June 25-26, 2018. Also presented at ADB Workshop on Technology and Aging Workforce Maximize the Gains from Longevity and Long Working Life, Asiatic Research Institute, Korea University, Republic of Korea, 17-18 May 2018. We thank Yongok Choi, HyungGun Kim, Kiseok Hong and anonymous referees for providing valuable comments. We also thank Dung Ly-My for her research assistance. We acknowledge the support by the National Research Foundation of Korea Grant funded by the Korean Government (NRF-2017S1A5A2A03069146). Part of the research was done while Kwanho Shin was visiting Hitotsubashi Institute for Advanced Study as an adjunct professor.

+ Department of International Trade and Business, Kangwon National University, Chuncheon, 200-701, Republic of Korea. Phone: +82-33-250-6186; Fax: +82-33-256-4088; Email: hhlee@kangwon.ac.kr

${ }^{++}$(corresponding author) Department of Economics, Korea University, 5-1 Anam-Dong, Sungbuk-Ku, Seoul, Republic of Korea 136-701, khshin@korea.ac.kr
} 


\section{Introduction}

During the past few decades, most countries have experienced rapid changes in the age structure of their populations. For example, many East Asian countries have experienced a rapid shift in their age structure from a high youth-age population share to a high working-age population share and then to a high old-age population share. A rapid increase in working-age population share occurred in these countries during the 1970s and 1980s and this transition contributed substantially to East Asia's so-called economic miracle (Bloom and Williamson, 1998). Such a period of demographic dividend did not last long, however. These countries in Asia are now experiencing population aging at a rate higher than in any other regions.

As compared to medium-age workers (more generally, the working-age population), the elderly participate less actively in the labor force, their productivities are lower (Skirbekk, 2003; Aiyar, et al, 2016; Liu and Westelius, 2016), and they save less (Park and Shin, 2012; Horioka and Niimi, 2017). Thus, if a number of people in the working-age population are replaced by an equivalent number among the old-age population, other things being equal, then population aging in a country will hamper its economic growth, thus imposing a significant demographic burden. ${ }^{1}$

However, previous empirical studies examining the overall impact of population aging on economic growth have often yielded mixed results, as reviewed in Nagarajan, et al. (2013). For example, using a panel dataset for the period 1960-2005, Bloom, Canning, and Finlay (2008) find that the effect of old age on growth is negative in the short run but insignificant in the long run. Similarly, using the partial adjustment model in a panel framework and a dataset for 80 countries for the period 1960-2005, Lee et al. (2013) find that population aging does not appear to hold back economic growth. More recently, Acemoglu and Restrepo (2017) argue that countries experiencing more rapid aging have grown more rapidly because of the more rapid adoption of automation technologies in these countries.

\footnotetext{
1 The negative burden of aging can be mitigated by behavioral responses such as higher savings for retirement, higher investment in education, and greater labor force participation. This line of argument can be found in Bloom, Canning, and Finlay (2008), Bloom, Canning, and Fink (2008), and Bloom, Canning and Fink (2011).
} 
In contrast, using a sample of 142 countries for the period 1960-2014, Lee, Shin, and Park (2017) find that population aging has a negative impact on economic growth in both the short run and the long run. Eggertson et al. (2017) show that in a more recent period (2008-2015), as compared to the period 1990-2008, the correlation between aging and GDP growth has become negative. Maestas et al. (2016) find that using the U.S. states data for the period 1980-2010, population aging decreases the growth rate of GDP per capita.

Most, if not all, previous studies used old-age population share or old-age dependency ratio as a proxy for aging and presume that the effect of population aging on economic growth is linear, irrespective of the level of population aging. However, population aging may impact economic growth negatively only when it reaches a certain high level and its impact gets stronger as population aging deepens.

One of the major reasons might be the changing structure of the population. One may expect that as the old-age population share increases, there will be relatively fewer people included in the working-age population. However, as the old-age population share increases, the sum of the youth-age and working-age population shares should decrease. Therefore, an increasing old-age population share may coincide with an increasing working-age population share if the youth-age population share decreases at a higher rate.

Indeed, in the early stages of a demographic shift in most countries, as the old-age population share increases, the working-age population share also tends to increase. This is illustrated in Figure 1. As can be seen in the figure, Japan's old-age population (65 and above) share has been increasing, from 5.6\% in 1960 to $26.6 \%$ in 2016. During this period, Japan's old-age dependency ratio also increased from $8.8 \%$ to $43.9 \%$. However, the working-age population share increased from $64.5 \%$ in 1960 to $69.8 \%$ in 1992 and since then began to decrease. The figures in the right panel reveal that this is also true for Republic of Korea: both the old-age share and the old-age dependency ratio have increased while the working-age population share has increased, from $53.4 \%$ in 1960 to $73.4 \%$ in 2013 . Only from 2014 did the working-age share begin to decrease.

$<<$ Insert Figure 1 $>>$ 
Figure 2(A) redraws such a remarkable relationship between the old-age population share and the working-age population share. In the case of Japan, until the old-age population share reached $12.3 \%$ in the year 1991, the annual increases in the old-age population share were accompanied by increases in the working-age population share. Since then, the working-age population share has decreased, while the old-age population share has increased. In the case of Republic of Korea, until the old-age share reached $11.5 \%$ in 2013, population aging progressed, while the working-age population increased. As seen in Figure 2(B), a very similar pattern is also observed if the old-age dependency ratio replaces the old-age share.

\section{$<<$ Insert Figure 2 $>>$}

As long as the demographic dividend due to the increasing share of working-age population is greater than the demographic burden due to the increasing share of old-age population, the "overall" effect of population aging on economic growth may not necessarily be significantly negative. In this study, therefore, we systematically show that the negative effects of population aging on economic growth become visible only when population aging reaches a certain high level and its effects become more strongly visible as population aging deepens.

Indeed, the nonlinear relationship disappears if we instead use lowering of working-age population share as a proxy for aging. As shown in the next section, actually this is exactly what theory suggests. Empirically we also find that the relation between aging and economic growth is successfully described by a linear relationship if working-age population share is used. Hence whether the relationship is linear or nonlinear depends on which variable we use for the proxy for aging. ${ }^{2}$

The remainder of this paper is organized as follows. Section 2 explains the empirical framework. Section 3 reports and discusses the main results. Lastly, provided in Section 4 are a summary and concluding remarks.

\section{Empirical specification}

2 We thank an anonymous referee for pointing out this. 
It is assumed that the aggregate output is determined by a three-factor Cobb-Douglas production function ${ }^{3}$ :

$$
Y=A K^{\alpha} H^{\phi} L^{1-\alpha-\phi}
$$

where $\mathrm{Y}$ is gross domestic product (GDP), $\mathrm{K}$ is physical capital, $\mathrm{H}$ is human capital, $\mathrm{L}$ is labor force, and A is the productivity level. We normalize Equation (1) by dividing both sides by population, $\mathrm{P}$, and then take the natural logarithm of both sides; we thus obtain:

$$
\ln y=\ln A+\alpha \ln k+\phi \ln H+(1-\alpha-\phi) \ln (L / P)-\phi \ln P
$$

where y is GDP per capita and $\mathrm{k}$ is physical capital per capita. By taking the time difference, Equation (2) becomes:

$$
\Delta \ln y=\Delta \ln A+\alpha \Delta \ln k+\phi \Delta \ln H+(1-\alpha-\phi) \Delta \ln \left(\frac{L}{P}\right)-\phi \Delta \ln P
$$

where $\Delta$ represents the time difference. Equation (3) clearly shows that the growth rate of per capita GDP depends positively on the growth rate of a country's labor force in the total population.

It is assumed that $\mathrm{L}$ is proxied by the working age population, so that

$$
\Delta \ln y=\Delta \ln A+\alpha \Delta \ln k+\phi \Delta \ln H+(1-\alpha-\phi) \Delta \ln \left(\frac{P-C-O}{P}\right)-\phi \Delta \ln P
$$

where $\mathrm{C}$ is the youth population and $\mathrm{O}$ is the old population. Thus, Equation (4) also suggests that a country's growth rate of per capita GDP depends negatively on aged population as well as youth population. It should be noted, however, that Equation (4) suggests that the relationship between population aging, measured by increase in the old population share $\left(\Delta \ln \left(\frac{O}{P}\right)\right)$, and economic growth is not linear.

\footnotetext{
${ }^{3}$ Below we follow the exposition of Lee et al. (2013) and Lee, Park, and Shin (2017) in deriving the estimation equation.
} 
We use the same dataset as was utilized by Lee, Shin, and Park (2017). GDP per capita growth rates at five-year intervals are calculated for 142 countries for the period 1960-2014, using the Penn World Table version 9.0's national-accounts real GDP (RGDPNA). ${ }^{4}$ As is common in the literature, we minimize the influence of business cycle fluctuations by using five-year averages of variables for eleven sub-periods: (Period 1: 1960-1964), (Period 2: 1965-1969), (Period 3: 1970-1974), (Period 4: 1975-1979), (Period 5: 1980-1984), (Period 6: 1985-1989), (Period 7: 1990-1994), (Period 8: 1995-1999), (Period 9: 2000-2004), (Period 10: 2005-2009), and (Period 11: 2010-2014). We then calculate average growth rates of GDP per capita for each 5-year interval.

Following Mankiw, Romer, and Weil (1992), we assume that y approaches its steady state with partial adjustment and that the steady state is determined by equation (2). As illustrated in Lee et al. (2013), if we further assume that the change in the productivity of the economy, $\Delta \ln (A)$, is influenced by the initial levels of physical capital, human capital and trade openness, Equation (5) can be converted to the following empirically testable equation:

$$
\begin{aligned}
& \left(\ln r g_{p d n a} a_{i t}-\ln r g p d n a_{i t-1}\right)=-\delta \ln r g d p o_{i t-1}+\beta_{1} \ln P o p_{i t-1}+\beta_{2} \text { Young }_{i t-1}+\beta_{3} \text { Old }_{i t-1} \\
& +\beta_{4} \ln C a p_{i t-1}+\beta_{5} h c_{i t-1}+\beta_{6} \ln T r d_{i t-1} \\
& +\beta_{7}\left(\ln P \text { op }_{i t}-\ln \mathrm{Pop} \mathrm{p}_{i t-1}\right)+\beta_{8}\left(\text { Young }_{i t}-\text { Young }_{i t-1}\right)+\beta_{9}\left(\text { Old }_{i t}-\text { old }_{i t-1}\right) \\
& +\beta_{10}\left(\ln C a p_{i t}-\ln C a p_{i t-1}\right)+\beta_{11}\left(h c_{i t}-h c_{i t-1}\right)+\beta_{12}\left(\ln T r d_{i t}-\ln \operatorname{Trd} d_{i t-1}\right)+\mu_{i}+\mu_{t}+\xi_{t}
\end{aligned}
$$

where

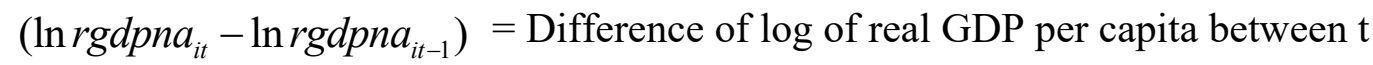
and t-1 [in 2011 national prices; PWT 9.0]

$\ln r g d p o_{i t-1}=$ Log of initial level of output-side real GDP per capita [in 2011

US\$; PWT 9.0 $]^{5}$

$\ln$ Cap $=$ Log of capital stock at PPPs [in million 2011 US\$; PWT 9.0]

\footnotetext{
${ }^{4}$ Among the five types of real GDP in the Penn World Table 9.0 reports, real GDP using national-accounts $\left(\mathrm{RGDP}^{\mathrm{NA}}\right.$ ) is recommended by PWT for studies on cross-country growth rates. 2014 is the latest year for which PWT version 9.0 is available.

${ }^{5}$ Instead of real GDP per capita in local currency, real GDP per capita in US\$ is used for the initial level of GDP per capita, for the sake of comparison across countries.
} 
$h c=$ Human capital index [PWT 9.0 $]^{6}$

$\ln$ Pop $=$ Log of total population [World Bank's WDI]

Young $=$ YoungSh (Population aged below 15 as $\%$ of total) or YoungDep

(100*population aged below 15/population aged between 15 and 65)

[World Bank's WDI]

Old $=$ OldSh (Population aged above 65 as \% of total) or OldDep (100*population

aged above 65/population aged between 15 and 65) [World Bank's WDI]

$\ln T r d=$ Log of trade as \% of GDP (World Bank's WDI).

Note that $\delta$ is the rate of adjustment (or speed of conversion), which is bounded by zero and one. We estimate panel regressions with country fixed effects. ${ }^{7}$ We also include period dummies as explanatory variables to control time-fixed global factors such as global growth, global capital market shocks, and so forth.

As explained in Lee et al. (2013), we can interpret the coefficients on level variable as the long-run effects, whereas the coefficients on the first-difference variables can be interpreted as the short-run adjustments to contemporaneous changes in the determinants of $\ln y$.

Lastly, as seen from Equation (4), the relationship between population aging $\left(\Delta \ln \left(\frac{O}{P}\right)\right)$ and economic growth is not linear. Indeed, this point was briefly illustrated in Section 1 and will be further illustrated in Section 3. Therefore, we need to add a quadratic term of old age population share in Equation (5). ${ }^{8}$ Further, we will utilize young-and old-age population shares as percentages of total population as well as young- and old-age dependency ratios (i.e. young and old-age population relative to working age population).

In contrast, as seen from Equations (2) and (3), the relationship between change in working-age population share $\left(\Delta \ln \left(\frac{L}{P}\right)\right)$ and economic growth $(\Delta \operatorname{lny})$ is linear. This shows

\footnotetext{
${ }^{6}$ For details of human capital index, see http://www.rug.nl/ggde/docs/human_capital_in_pwt_90.pdf

${ }^{7}$ Some researchers rely on the system GMM to estimate dynamic panel equations that take a similar form to Equation (5). Note that, since we use output-side real GDP per capita (RGDPO) instead of national-accounts real GDP per capita (RGDPNA) as the initial level of real GDP per capita, our specification is not for dynamic panel equations. While RGDPNA is recommended to calculate real growth rates, for the comparison of per capita GDP across countries, RGDPO is preferred by PWT.

${ }^{8}$ When we add a cubic term of old-age population share, its coefficient is estimated to be statistically insignificant.
} 
that depending on how we proxy for aging, i.e. using working-age population share or old-age population share, the specification can be either linear or nonlinear.

\section{Empirical results}

\subsection{Benchmark results}

Columns (2) and (3) of Table 1 report the estimated results of Equation (5), whereas Column (1) reports the result when the working-age population share is included in place of the old-age and young-age variables. These results are identical to those reported in Tables 1 and 2 in Lee, Shin, and Park (2017). The coefficients both on the initial value of old-age population share and on its change are negative and significant. Therefore, population aging may have a negative impact on economic growth not only in the short run but also in the long run. More specifically, a one percentage point increase in the old-age population share decreases the five-year economic growth rate by 2.0 percentage points in the long run, leading to a lower steady state income per capita. If the change in the old-age share increases by one percentage point over a 5-year period, the five-year economic growth rate will decrease by 3.4 percentage points.

\section{$<<$ Insert Table 1 $>>$}

Column (3) of the table reports the results when old and young population dependency ratios (YoungDep and OldDep) are used in place of the old and young population shares (YoungSh and OldSh). These results also reveal that population aging has a negative impact on economic growth both in the long run and in the short run. In terms of the size of the estimated coefficients, old-age population, as compared to youth population, has roughly double the negative impact on economic growth. ${ }^{9}$

As seen in Section 2, a linear regression may not reveal the association between population aging and economic growth because the true relationship is nonlinear. Column (4), therefore,

\footnotetext{
9 Among the control variables, the coefficient on the initial value of the log of population is negative and significant. Countries with a larger amount of physical capital are found to enjoy higher rates of economic growth both in the short run and in the long run. Countries that are more open to trade are also found to grow faster.
} 
reports the results with the addition of a quadratic term of old-age population share (OldSh). Since the coefficient of a cubic term is not statistically significant, we do not explore higher order terms. As expected, the quadratic term of old-age population share enters with a negative and significant coefficient, while OldSh is no longer statistically significant. A similar result is obtained when old-age dependency ratio (OldDep) is used instead of OldSh.

In Tables 2(A) and (B) and in Figures 3(A) and (B), we present how the marginal effect of population aging on economic growth changes as population aging deepens. They show clearly that, as either old-age population share (Table 2(A) and Figure 3(A)) or old-age dependency ratio (Table 2(B) and Figure 3(B)) increases, its marginal effect on economic growth becomes greater. Standard errors and 95\% confidence levels are calculated by the Delta-method. In Table 2(A), the marginal effect of OldSh becomes statistically significant at the five percent level only when it reaches 10 percent of total population. As population aging deepens, its negative marginal effect on economic growth continues to become greater economically and more significant statistically. More specifically, at the 10/ 15/ 20 percent level of old-age population, a one-percentage point increase in old-age population decreases the five-year economic growth rate by 1.6/ 2.5/ 3.5 percentage points. Table 2(B) also indicates that at the 15/20/ 25 percent level of old-age dependency ratio, a one-percentage point increase in old-age dependency ratio decreases the five-year economic growth rate by $0.6 / 1.1 / 1.6$, respectively. ${ }^{10}$

$$
\begin{aligned}
& <<\text { Insert Tables 2(A) and (B) }>> \\
& <<\text { Insert Figures 3(A) and (B) }>>
\end{aligned}
$$

In order to confirm the robustness of our finding that there exists a nonlinear relationship between old-age population share and economic growth, we explore various specifications in Table 3. In Table 3A, we report estimation results when a quadratic term of young-age population share is also included. In column (1)-(3), we ignore short-term adjustment terms by assuming that the adjustment speed is infinite. In columns (1) and (4), we do not include

10 As a reference, old-age population share and old-age dependency ratio of the Republic of Korea in 2010 were 10.3 and 14.6, respectively, while those of Japan in 2010 were 22.5 and 35.1 , respectively. 
human capital and trade openness as regressors. In columns (2) and (5), we exclude just trade openness. Interestingly we find that the coefficient of a quadratic term of young-age population share is not statistically significant in any specification. In contrast, the coefficient of a quadratic term of old-age population share is statistically significant at the 5 percent level in columns (2), (3) and (5) and at the 10 percent level in column (6). In Table 3B, we report that same regression results except that we exclude young-age population share from regressors. In this case, the coefficient of a quadratic term of old-age population share is even more statistically significant. It is statistically significant at the 1 percent level in columns (2), (3), (5) ad (6) and at the 5 percent level in the rest of the columns. Overall our findings strongly suggest that there exists a nonlinear relationship between population aging proxied by old-age population share and economic growth.

$<<$ Insert Table 3>>

However, as seen from equation (3), if we define population aging as lowering of working-age population share, the relationship between aging and economic growth can be linear. In Table 4, we report regression results when we use working-age population share as a regressor, instead of old-age population share (and young-age population share). In Table 4, the coefficient of a quadratic term of working-age population share is no longer statistically significant except in column (6) where it is marginally significant at the 10 percent level. Hence we conclude that the nonlinear relationship holds only when old-age population share is used as a proxy for aging.

$<<$ Insert Table 4>>

As briefly discussed in Section 1, the crucial point is that higher old-age population share does not necessarily coincide with lower working-age population share. Using the panel data for our empirical analysis, Figures 4-6 support this view. Specifically, Figure 4(A) reveals that countries with greater youth-age population shares are those with smaller working-age shares. Figure 4(B), however, reveals that the relationship between old-age share and working-age share is non-linear. For the countries with old-age population share of about $10 \%$ or smaller, a greater share of old-age population appears to coincide with a greater share of 
working-age population. ${ }^{11}$ However, if old-age population share exceeds the 10 percent level, higher old-age population shares appear to be associated with smaller working-age population shares. $^{12}$

$<<$ Insert Figure 4>>

Figure 5 illustrates the same relationship in changes. Figure 5(A) reveals that countries with greater increases (five-year) in youth-age population share are those with smaller rates of change in working-age population share. However, Figure 5(B) reveals that the relationship between changes in old-age population share and changes in working-age population share is not clearly identifiable.

In Table 5, to show the above evidence more systematically, we report regression results. In Table 5A, we report estimation results for the nonlinear specifications in levels between working-age population share and old-age population share (or young-age population share). In all columns the dependent variable is working-age population share. The regressors are both linear and quadratic terms of old-age population share (columns (1)-(3)) and young-age population share (columns (4)-(6)). Columns (1) and (4) are pooling OLS estimation, columns (2) and (5) are panel estimation with random effects and columns (3) and (6) are panel estimation with country-specific and period-specific effects. In all columns, the coefficient of a quadratic term, irrespective of whether it is of old-age population share or of young-age population share, is statistically significant at the 1 percent level. Hence we find a strong evidence of the nonlinear relationship. However, the size of the coefficient is much larger for old-age population share (-.09, -.13, and -.16) than for young-age population share (-.01, -.01 and -.01), indicating that working-age population share has a much stronger nonlinear relationship with old-age population share than with young-age population share. Indeed, as shown in Figure 4(A), the relationship between young-age population share and working-age population share can be approximated by a linear relationship. However, as presented in Figure 4(B), the relationship between old-age population share and working-age

11 ARE (United Arab Emirates), QAT (Qatar), and BHR (Bahrain) appear to be outliers and hence in the regression analysis we check if dropping these three countries in the sample may affect our key results but we still find similar results.

12 We also find similar results when we examine the correlation between working-age share and old-age dependency ratio (defined as the ratio of old-age to working age population). 
population share can hardly be approximated by a linear relationship.

In Table 5B, we also report the regression results for the relationship in changes. The dependent variable is change in working-age population share. The regressors are both linear and quadratic terms of change in old-age population share (columns (1)-(3)) and of change in young-age population share (columns (4)-(6)). Here, again, the nonlinear relationship is much more pronounced for old population share. While the coefficient of a quadratic term of old population share is statistically significant at the 1 percent level in all columns (1)-(3), that for young-age population share is not statistically significant in columns (5) and (6).

$<<$ Insert Table 5(A) and (B) $>>$

The nonlinear relationship between working-age population share and old-age population share makes the relationship reversed as we group countries based on the degree of their aging level. Figure 6 illustrates this by grouping countries in three different levels of aging. Figure 6(A) clearly reveals that among the non-aged countries (old-age population share below 6.32, the average level in our sample), an increase in old-age population share generally coincides with an increase in working-age population share. However, Figure 6(B) reveals that for the group of aged countries (old-age population share $>6.32$ ), the relationship appears to be negative, and Figure 6(C) further reveals that such a negative relationship becomes stronger for the group of more aged countries (old-age population share $>10.0$ ).

\section{$<<$ Insert Figure 6>>}

A very similar pattern is observed even when we replace old-age population share with old-age population dependency ratio, which is defined as the ratio of old-age to working-age population. ${ }^{13}$

Thus, a linear regression may not reveal the true association between population aging and economic growth if old-age population share or old-age dependency ratio is used as a proxy for aging because when population aging is still at a low level, the positive impact of increasing working-age share on economic growth is simultaneously at play.

13 Not shown for the sake of brevity but available upon request. 


\subsection{Effects of population aging in different periods of time}

As discussed in Section 1, earlier studies in the literature often fail to find a statistically significant negative impact of population aging on economic growth. This might be due to the fact that the data used by earlier studies did not include the recent period of high population aging and hence with a relatively lower level of population aging, the negative impact of population aging was not captured.

In order to assess this possibility, we estimate Equation (6) while restricting the sample to the period until the year 1999. The estimated results are reported in Columns (3) and (4) of Table 6. The corresponding results when using the whole sample are also reported in Columns (1) and (2) for the sake of comparison. As expected, the estimated coefficients of population aging variables (OldSh and OldDep) are no longer statistically significant, even though they enter with negative signs.

In order to assess whether the negative effects of population aging on economic growth have been continuously growing stronger over time, we re-estimated Equation (5) with the addition of an interaction term of the population aging variables (OldSh and OldDep) and a period variable. Note that there are eleven periods in our sample, as explained in Section 3.1. As seen in Columns (5) and (6), the interaction terms enter with very significant negative coefficients. Tables 7(A) and (B) as well as Figures 7(A) and (B) illustrate that as the data include more recent periods, the marginal effect of population aging on economic growth becomes greater.

$$
\begin{aligned}
& <<\text { Insert Tables 7(A) and (B) }>> \\
& <<\text { Insert Figures 7(A) and (B) }>>
\end{aligned}
$$

This result is consistent with the findings of Eggertson et al. (2017), who find a negative correlation between aging and GDP growth when they use the data for the period 2008-2015 instead of 1990-2008. Thus, as the world's aging population continues to grow older dramatically (United Nations, 2017), it is likely that the world may enter an age of secular stagnation, as suggested by Summers (2013; 2015) and Eggertson et al. (2017). 


\subsection{Effects of population aging in different groups of countries}

Rising life expectancy and decreasing fertility rate emerged first in more developed countries and hence population aging is more advanced in developed countries than in developing countries. If our findings above are correct, the negative impact of population aging on economic growth should be stronger in developed countries, where population aging is more advanced. Table 8 reports the estimated results for 29 OECD countries ${ }^{14}$ as well as for other countries. In our sample, the mean value of old-age population share for 29 OECD countries is 12.4 , while that for other countries is 4.9 .

When population aging is expressed as old-age population share (Columns 1 and 3), the absolute size of its coefficient is slightly smaller in the OECD country group but its significance is far greater in the OECD country group. When old-age dependency ratio is used, the population aging variable no longer carries a significant coefficient for non-OECD countries, while it continues to have a highly significant negative impact on economic growth for the 29 OECD countries.

$$
<<\text { Insert Table } 8>>
$$

We also ran regressions separately for more aged country groups and less aged country groups where more age country groups are compirised of countries whose old-age population shares or old-age dependency ratios are greater than the averages of the sample. As seen in Table 9, population aging has significant negative impacts on economic growth only in more aged country groups, not only in the long run but also in the short run.

$$
<<\text { Insert Table 9> }
$$

\section{Summary and concluding remarks}

\footnotetext{
14 Other OECD member countries which became members after 2010 are not included. They are Chile, Estonia, Israel, Latvia, Slovak Republic, and Slovenia. Even if these countries are also included in the OECD country group, the results are similar.
} 
Earlier studies in the literature often fail to find a negative impact of population aging on economic growth. This might be due to the fact that in early stages of population aging, most countries experiencing population aging do not experience a decline of the proportion of their working age population (15-64 years) to total population.

Using panel data for 142 countries for the period from 1950 to 2014, we have assessed effects of population aging on economic growth.

We have found that population aging proxied by old-age population share (or old-age dependency ratio) hampers economic growth to the greatest extent in countries where population aging has already reached a high level. The negative impact of population aging on economic growth becomes greater as population aging deepens. We have further found that the negative effect of population aging on economic growth has become greater in more recent years.

This nonlinear effect of aging is mainly driven by the fact that we use old-age population share as a proxy for aging. If we use lowering of working-age population share as a proxy for aging, the nonlinear relationship disappears: working-age population share is positively related to economic growth in a linear way. 


\section{References}

Acemoglu, D. and P. Restrepo (2017), "Secular Stagnation? The Effects of Aging on Economic Growth in the Age of Automation," American Economic Review, 107(5), 174-179.

Aiyar, Sh., C. Ebeke, and X. Shao (2016), "The Impact of Workforce Aging on European Productivity”, IMF Working Paper, WP/16/238, International Monetary Fund.

Bloom, D. E., D. Canning, and J. Finlay (2008), "Population Aging and Economic Growth in Asia," PGDA Working Paper No.40, Harvard School of Public Health.

Bloom, D. E. and D. Canning, and G. Fink (2008), "Population Aging and Economic Growth," PGDA Working Paper No.31, Harvard School of Public Health.

Bloom, D. E. and D. Canning, G. Fink (2011), "Implications of Population Aging for Economic Growth,” PGDA Working Paper No.64, Harvard School of Public Health.

Bloom, D. E. and J. G. Williamson (1998), "Demographic Transitions and Economic Miracles in Emerging Asia”, World Bank Economic Review, 12(30), 419-455.

Eggertson, G., M. Lancastre, and L. H. Summers (2017), “Aging, Output per capita and Secular Stagnation”, mimeo, Institute for New Economic Thinking. https://www.ineteconomics.org/research/research-papers/aging-output-per-capita-and-secular -stagnation

Feenstra, R. C., R. Inklaar, and M. P. Timmer (2015), "The Next Generation of the Penn World Table", American Economic Review, 105(10), 3150-3182.

Feenstra, R. C., R. Inklaar, and M. P. Timmer (2016), "What is new in PWT 9.0". (http://www.rug.nl/ggdc/docs/what_is_new_in_pwt90.pdf)

Horioka, C. Y. and Y. Niimi (2017), "Saving Behavior of Japanese Middle-aged and the Elderly”, ESRI International Conference on Empirical Analysis on Population Decline and Aging in the Japanese Economy, ESRI, Tokyo.

Lee, H.-H., H.-s Huh, Y.-Y. Lee, and J.-Y. Lim (2013), "Effects of Population Aging on Economic Growth: A Panel Analysis", Seoul Journal of Economics, 26(4), 401-432.

Lee, H.-H., K. Shin, and D. Park (2017), "Population Aging and Its Impact on Economic Growth: Implications for Korea”, Economic Analysis, ESTRI, 196, 159-178.

Liu, Y. and N. Westelius (2016), "The Impact of Demographics on Productivity and Inflation in Japan”, IMF Working Paper WP/16/237, International Monetary Fund.

Maestas, N., K. J. Mullen, and D. Powell (2016), "The Effect of Population Aging on Economic Growth, Labor Force and Productivity", NBER Working Paper No.22452.

Mankiw, N. G., Romer, D. and Weil, D., "A Contribution to the Empirics of Economic Growth," Quarterly Journal of Economics, May 1992, 152, 407-37. 
Nagarajan, R. A. A. C. Teixeira, and S. Silva (2013), "The Impact of an Ageing Population on Economic Growth: An Exploratory Review of the Main Mechanisms", FEP Working Papers No. 504.

Park, D. and K. Shin (2012), "Impact of Population Aging on Asia's Future Growth, in D. Park, S.-H. Lee, and A. Mason eds. Aging, Economic Growth, and Old-Age Security in Asia, Edward Elgar.

Shirakawa, M. (2012), "Demographic Changes and Macroeconomic Performance: Japanese Experiences", Opening remark at 2012 BOJ-IMES Conference.

Skirbekk, V. (2003), "Age and Individual Productivity: A Literature Survey", MPIDR Working Paper WP 2003-028, Max-Planck Institute for Demographic Research.

Summers, L. (2013), "Why Stagnation Might Prove to Be the New Normal", The Financial Times.

Summers, L. (2015), “Demand Side Secular Stagnation”, American Economic Review: Papers \& Proceedings., 105(5), 60-65.

United Nations (2017), World Population Prospects The 2017 Revision: Key Findings and Advance Tables, Department of Economic and Social Affairs, United Nations. 
Figure 1: Trend of population structure in Japan and Republic of Korea (1960-2016)

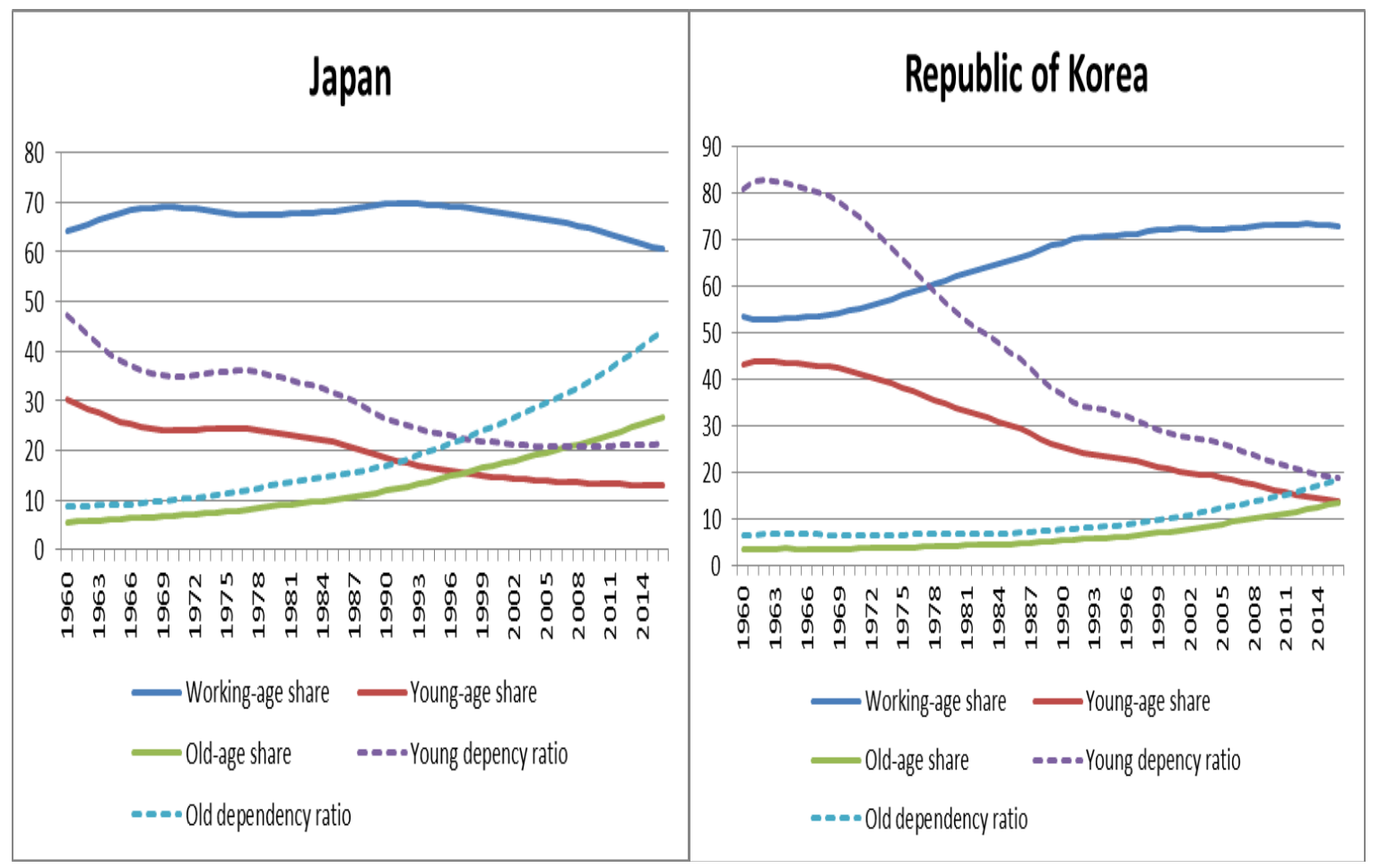

Notes: Young-age share: population ages 0-14 (\% of total), Working-age share: population ages 15-64 (\% of total), Old-age share: population ages 65 and above (\% of total); Young dependency ratio: $100 *$ young/work; and Old dependency ratio: $100 *$ old/work

Source: Authors' calculations based on World Bank's World Development Indicators 
Figure 2: Relationship between population aging and working-age population share in Japan and Republic of Korea (1960-2016)

(A) Old-age population share vs. working-age population share
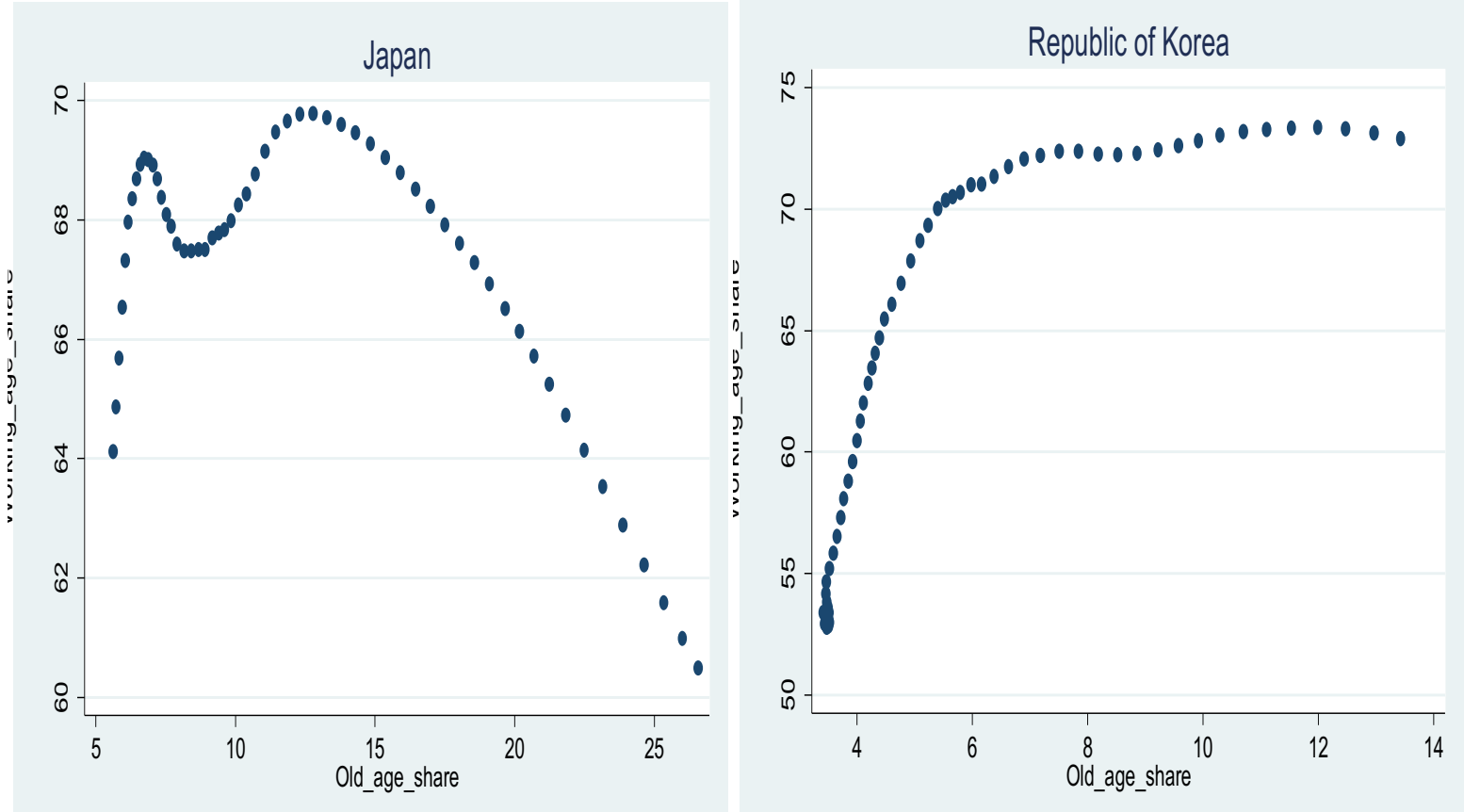

(B) Old-age dependency ratio vs. working-age share
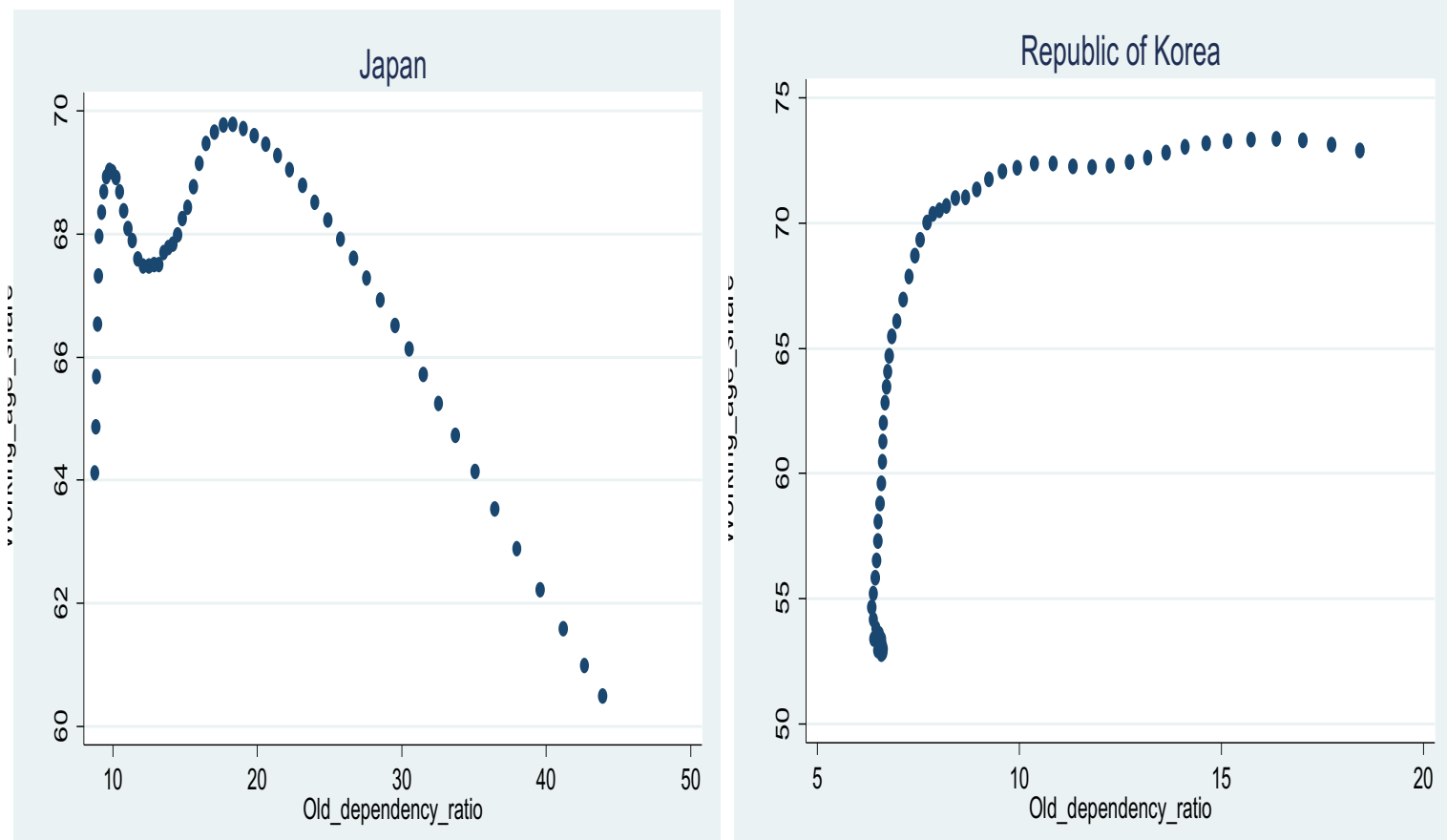

Notes: young_sh: population ages 0-14 (\% of total), work_sh: population ages 15-64 (\% of total), old_sh: population ages 65 and above (\% of total); young_dep: $100 *$ young/work; and old_dep: 100*old/work Source: Authors' calculations based on World Bank's World Development Indicators 
Figure 3: Average marginal effects of population aging on economic growth at different levels of population aging

(A)Old-age population share (OldSh)

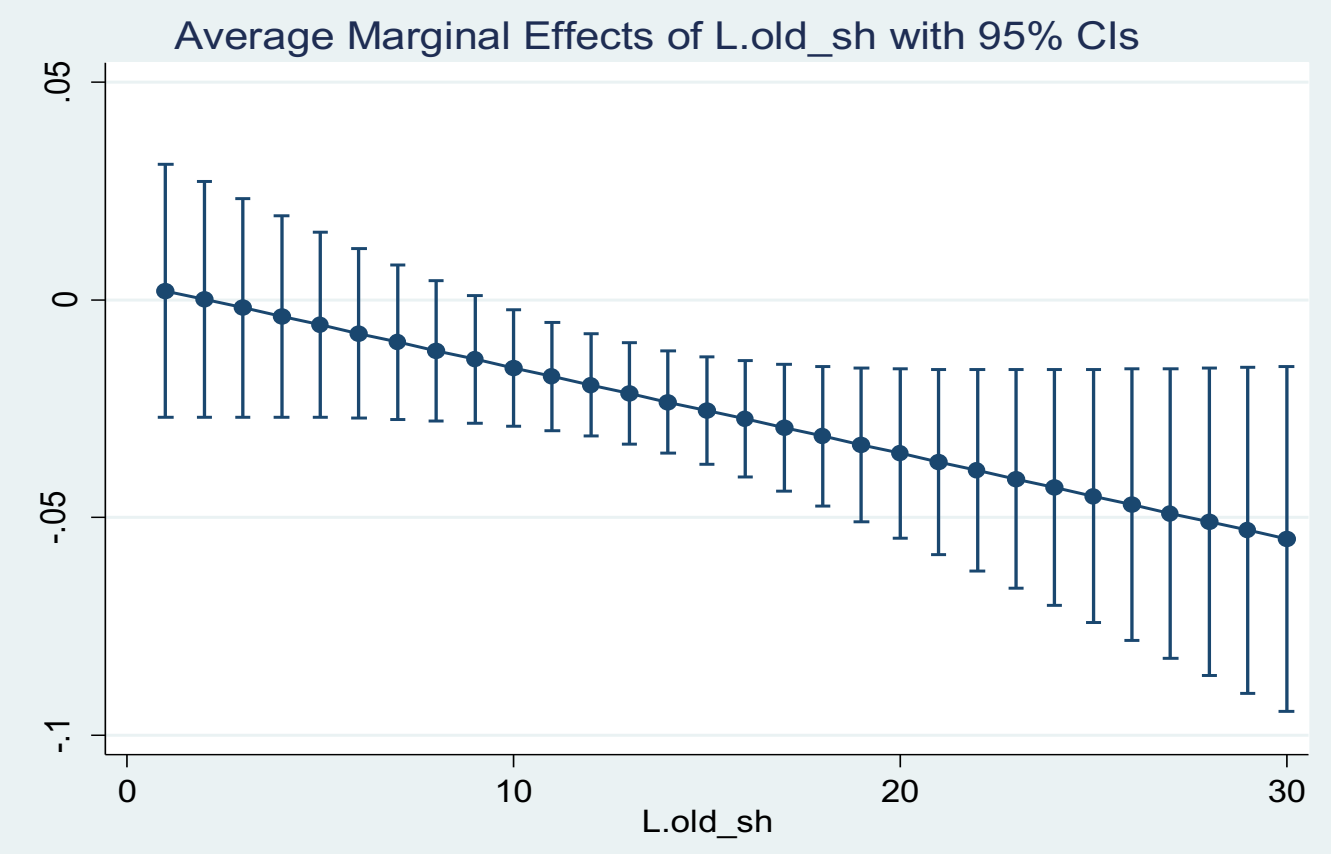

(B) Old-age dependency ratio (OldDep)

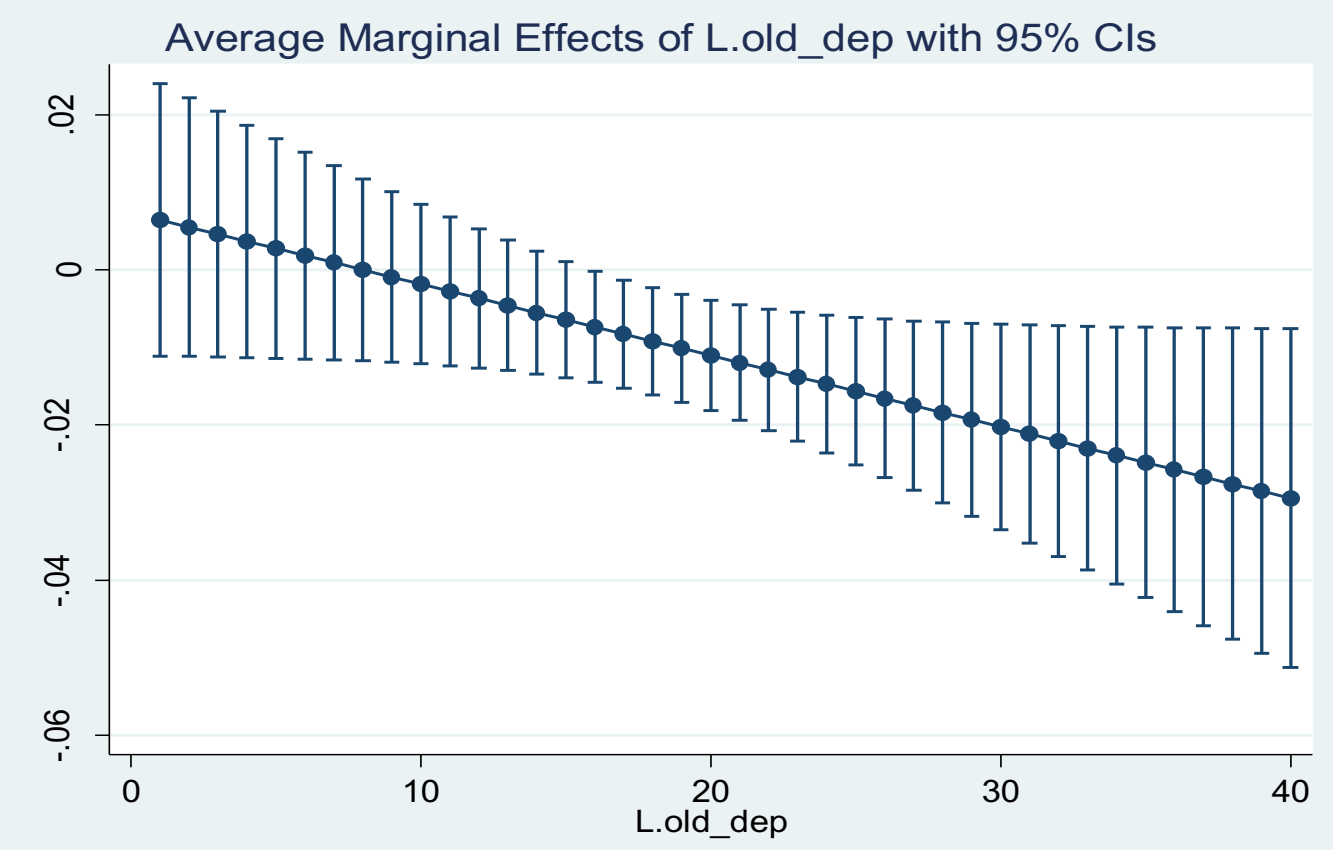

Source: Drawn from Table 2 
Figure 4: Relationship between demographic variables (1960-2014)

(A) Youth-age share vs. working-age share

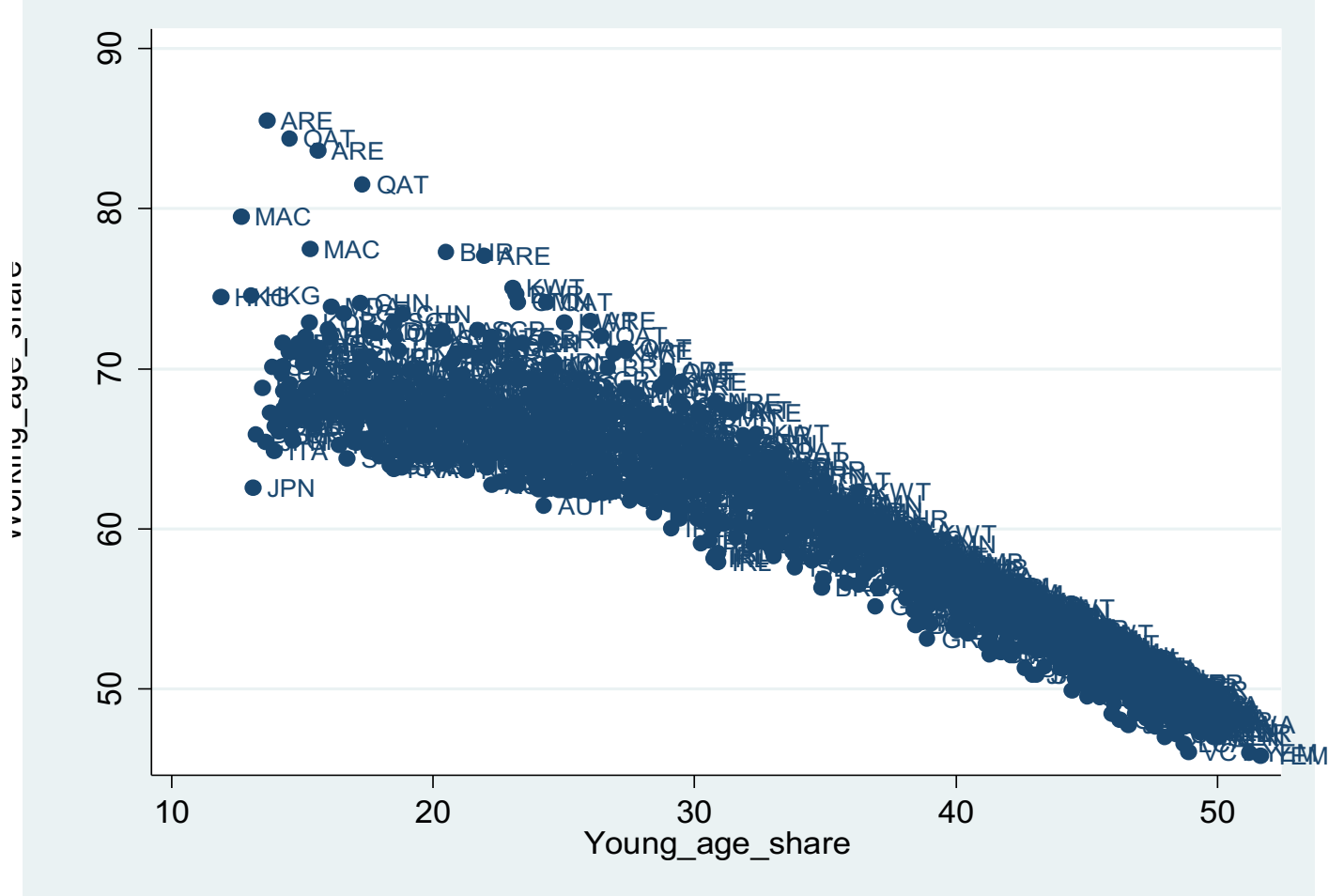

(B) Old-age share vs. working-age share

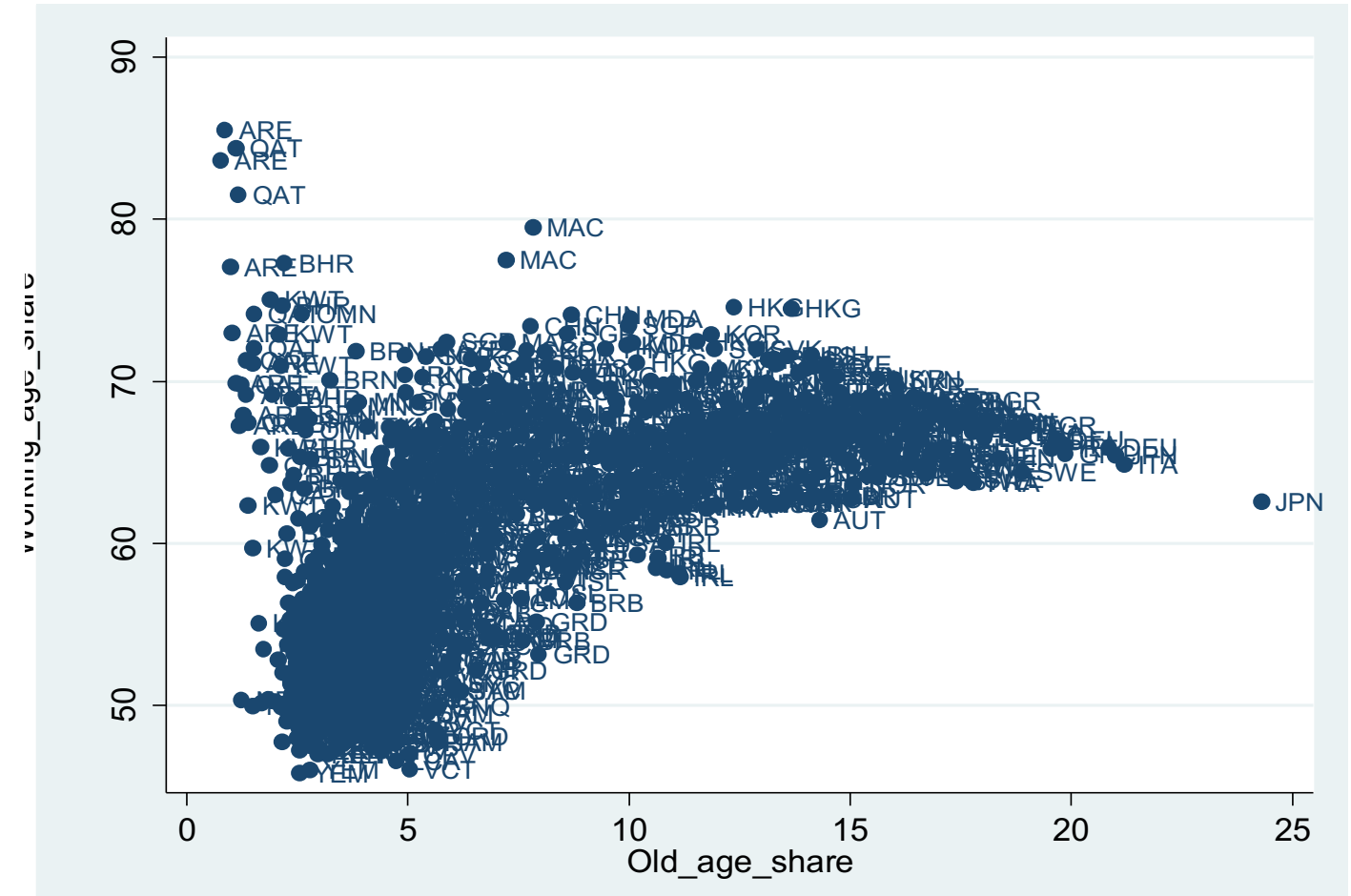

Notes: Young_age_share: population ages 0-14 (\% of total), Working_age_share: population ages 15-64 (\% of total), and Old_age_share: population ages 65 and above (\% of total).

Source: Authors' calculations based on World Bank's World Development Indicators 
Figure 5: Relationship between changes in demographic variables (1960-2014)

(A)Change in youth-age share vs. change in working-age share

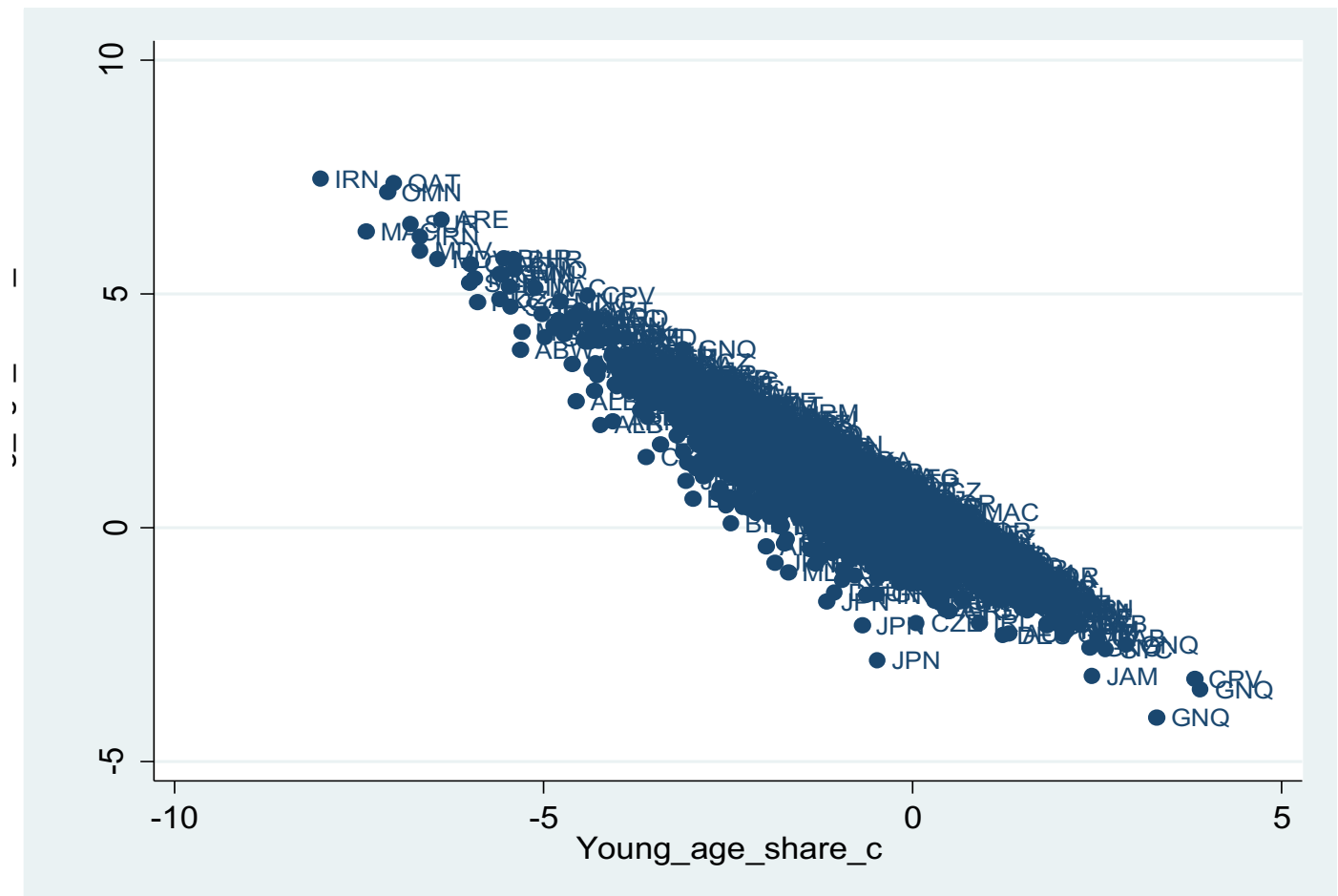

(B) Change in old-age share vs. change in working-age share

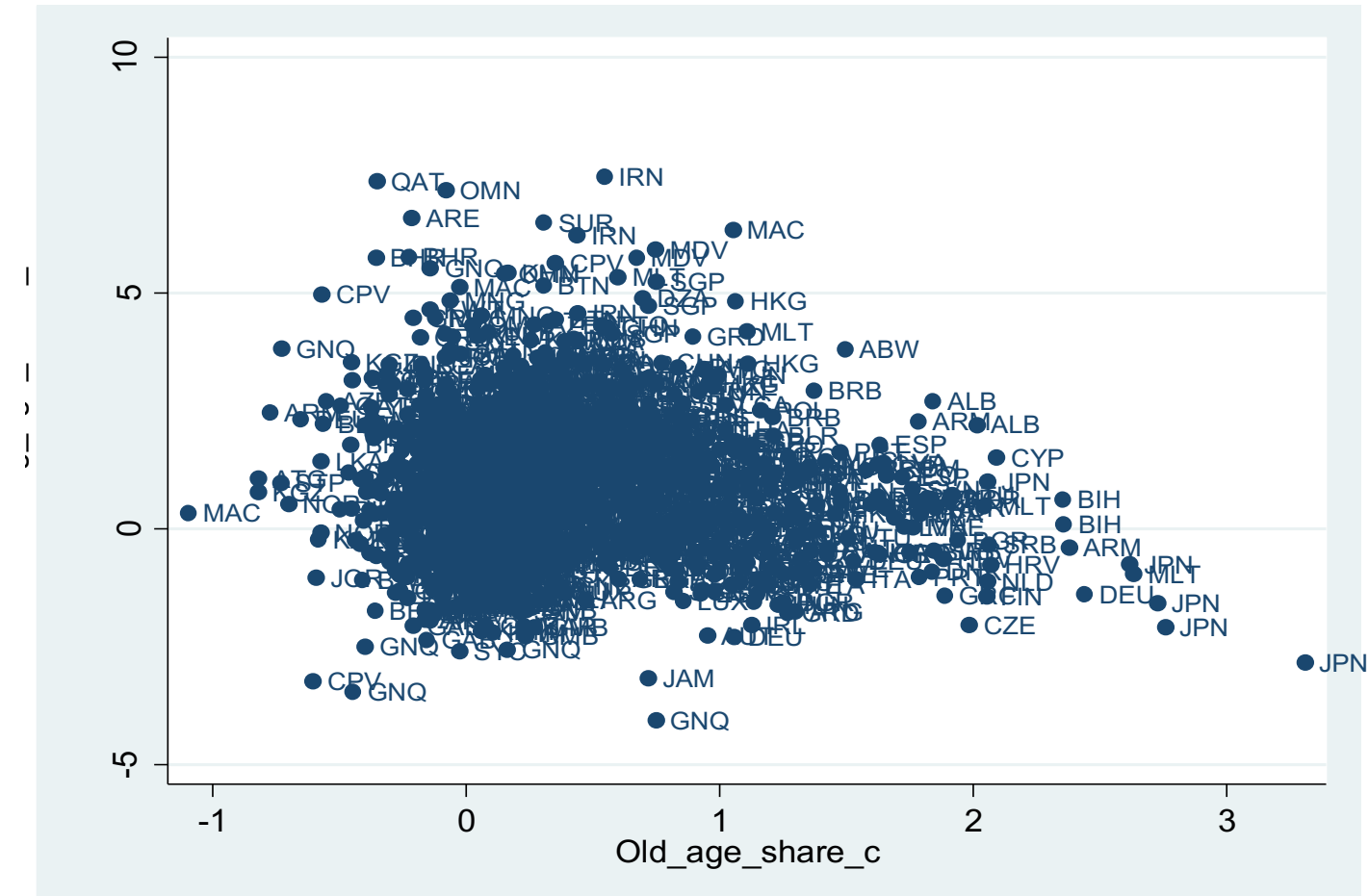

Notes: Young_age_share_c: Five-year changes in population ages 0-14 (\% of total), Working_age_share_c: Five-year changes in population ages 15-64 (\% of total), and Old_age_share_c: Five-year changes in population ages 65 and above (\% of total).

Source: Authors' calculations based on World Bank's World Development Indicators 
Figure 6: Relationship between change in old-age share vs. change in working-age share (1960-2014)

(A) Non-aged countries (old-age population share $<6.32$ )

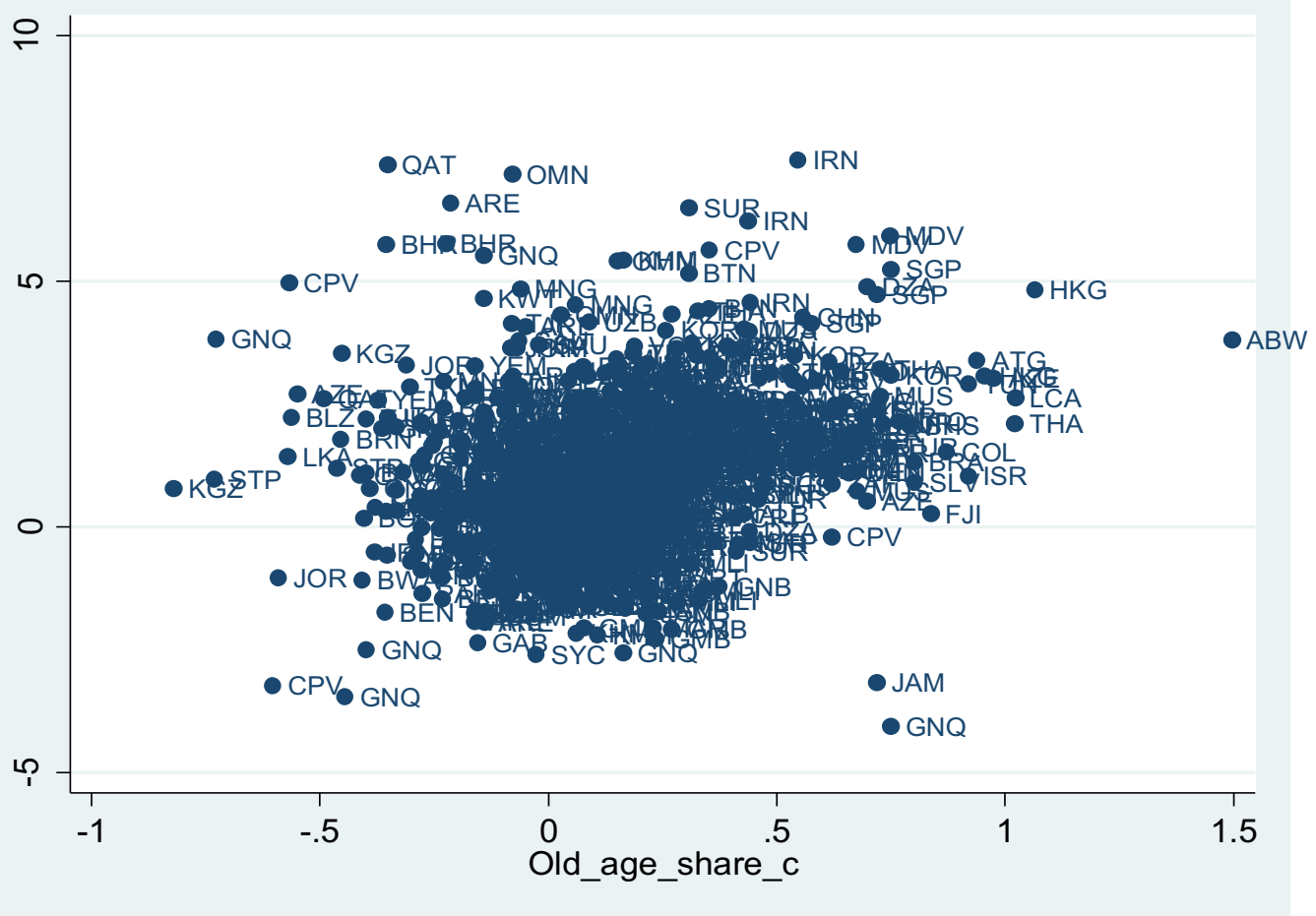

(B) Aged countries ((old-age population share $>6.32)$

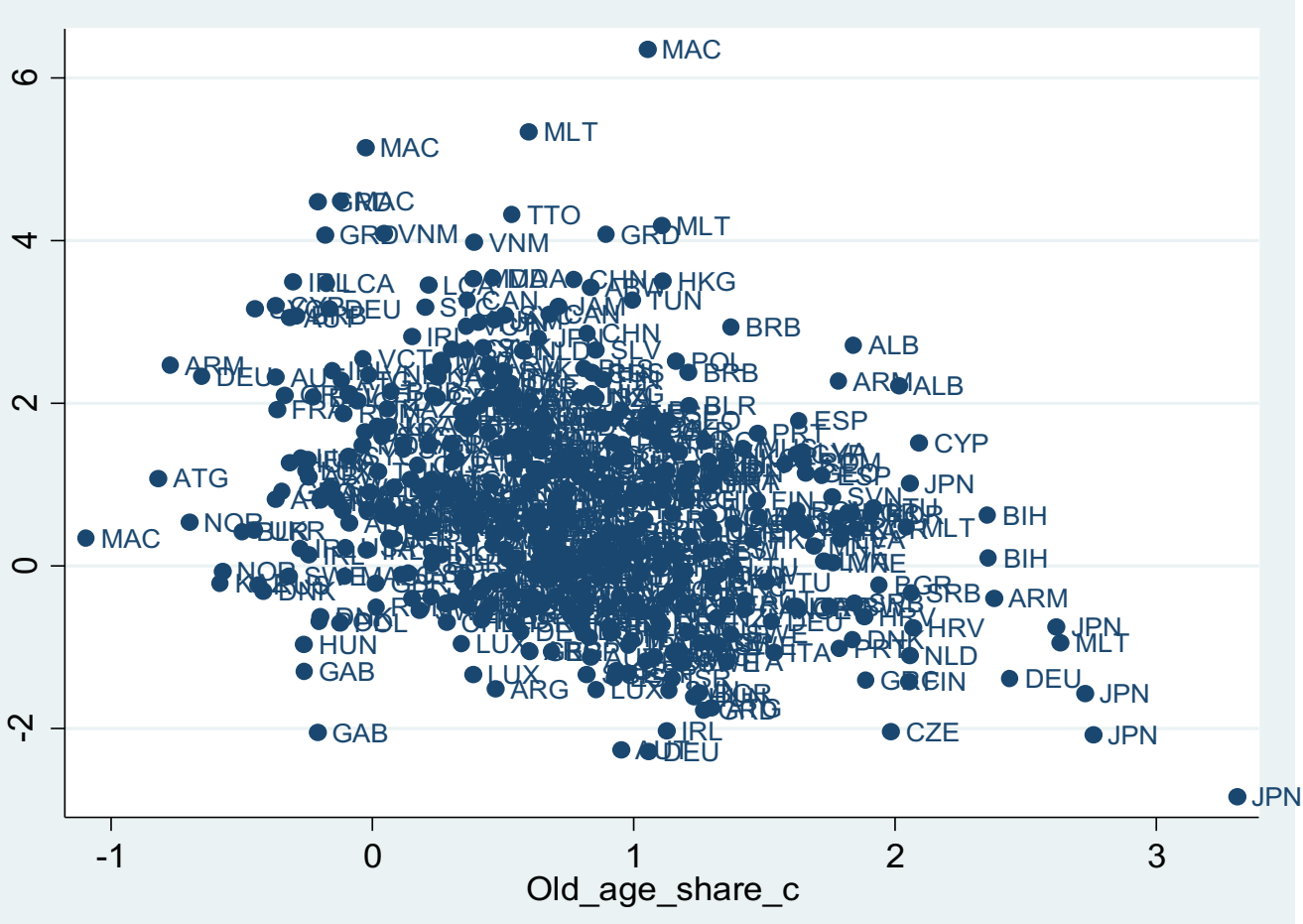


(C) Very aged countries ((old-age population share $>10.0)$

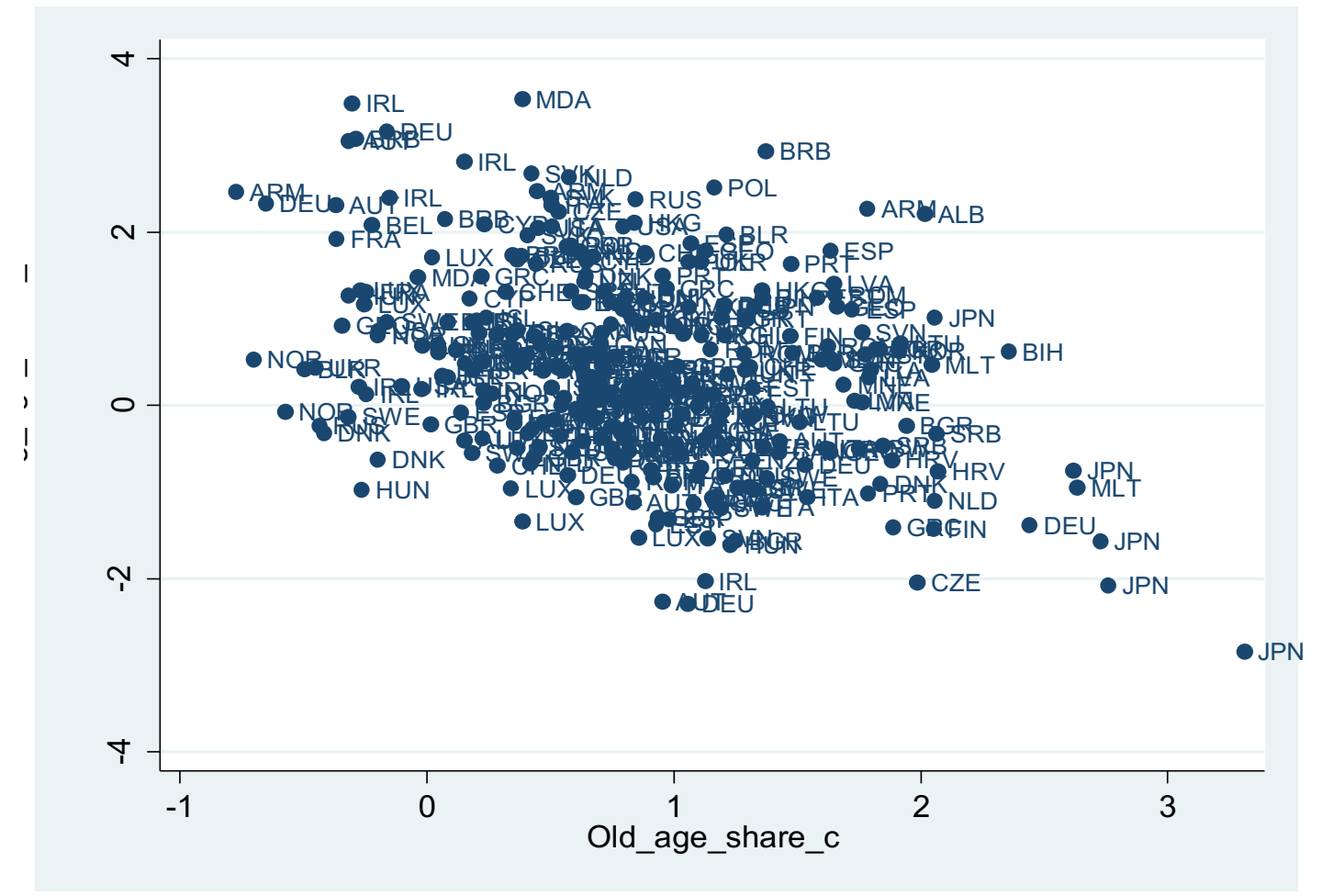

Notes: Working_age_share_c: Five-year changes in population ages 15-64 (\% of total), and Old_age_share_c: Five-year changes in population ages 65 and above (\% of total). In our sample, the average level of old-age population share is 6.32 .

Source: Authors' calculations based on World Bank's World Development Indicators 
Figure 7: Average marginal effects of population aging on economic growth at different perioods of time

(A) Old-age population share (OldSh)

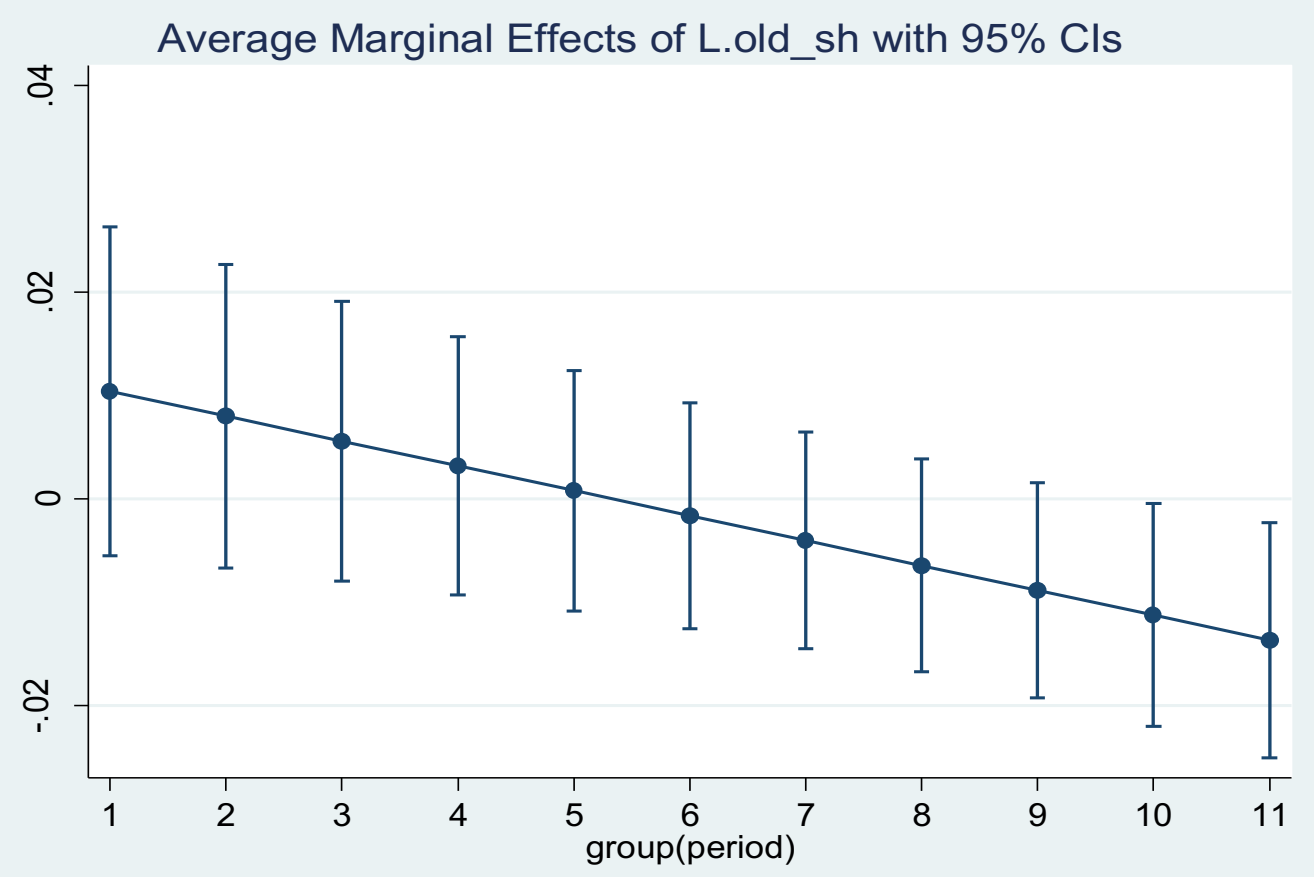

(B) Old-age dependency ratio (OldDep)

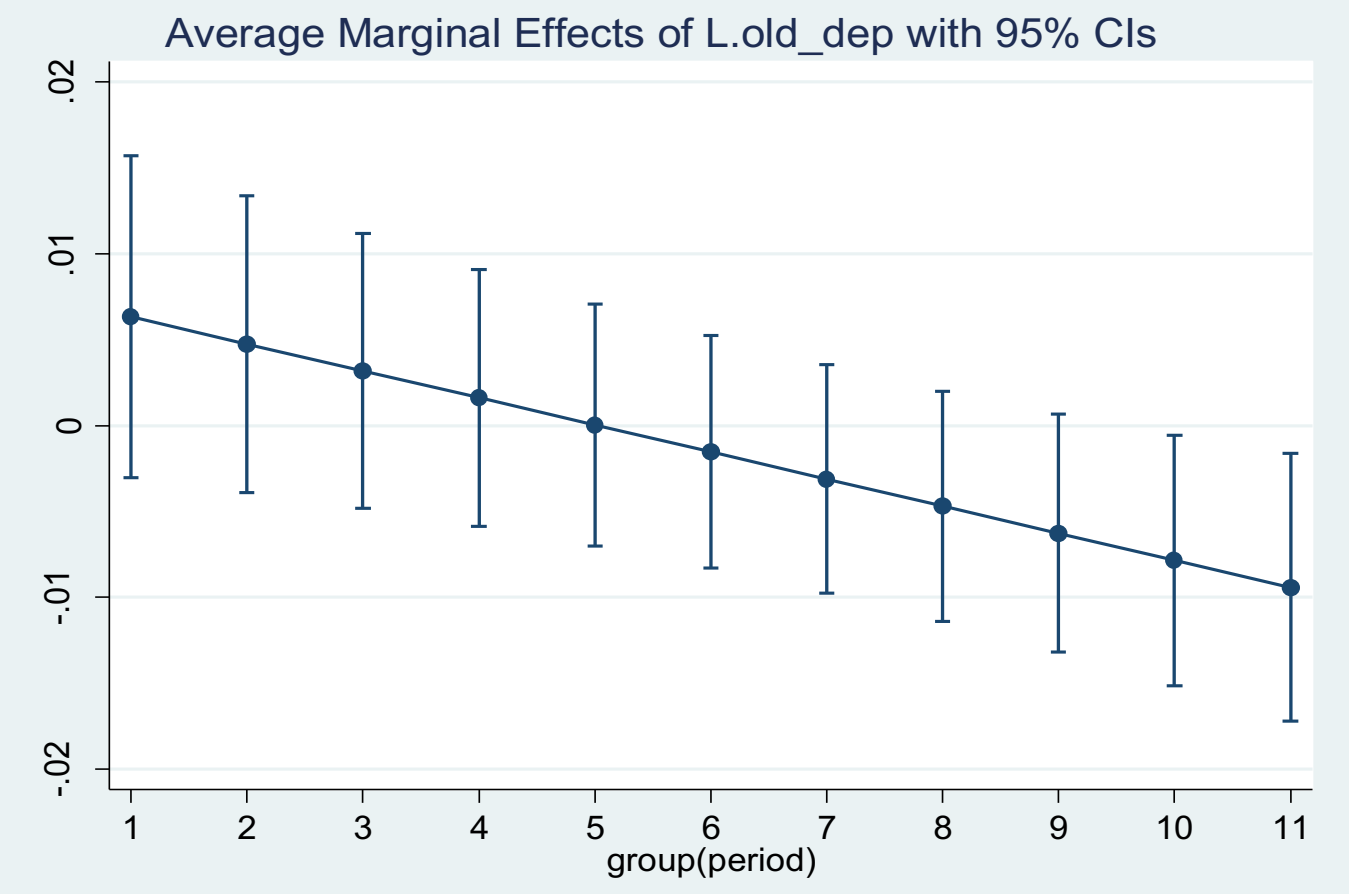

Source: Drawn from Table 4. 


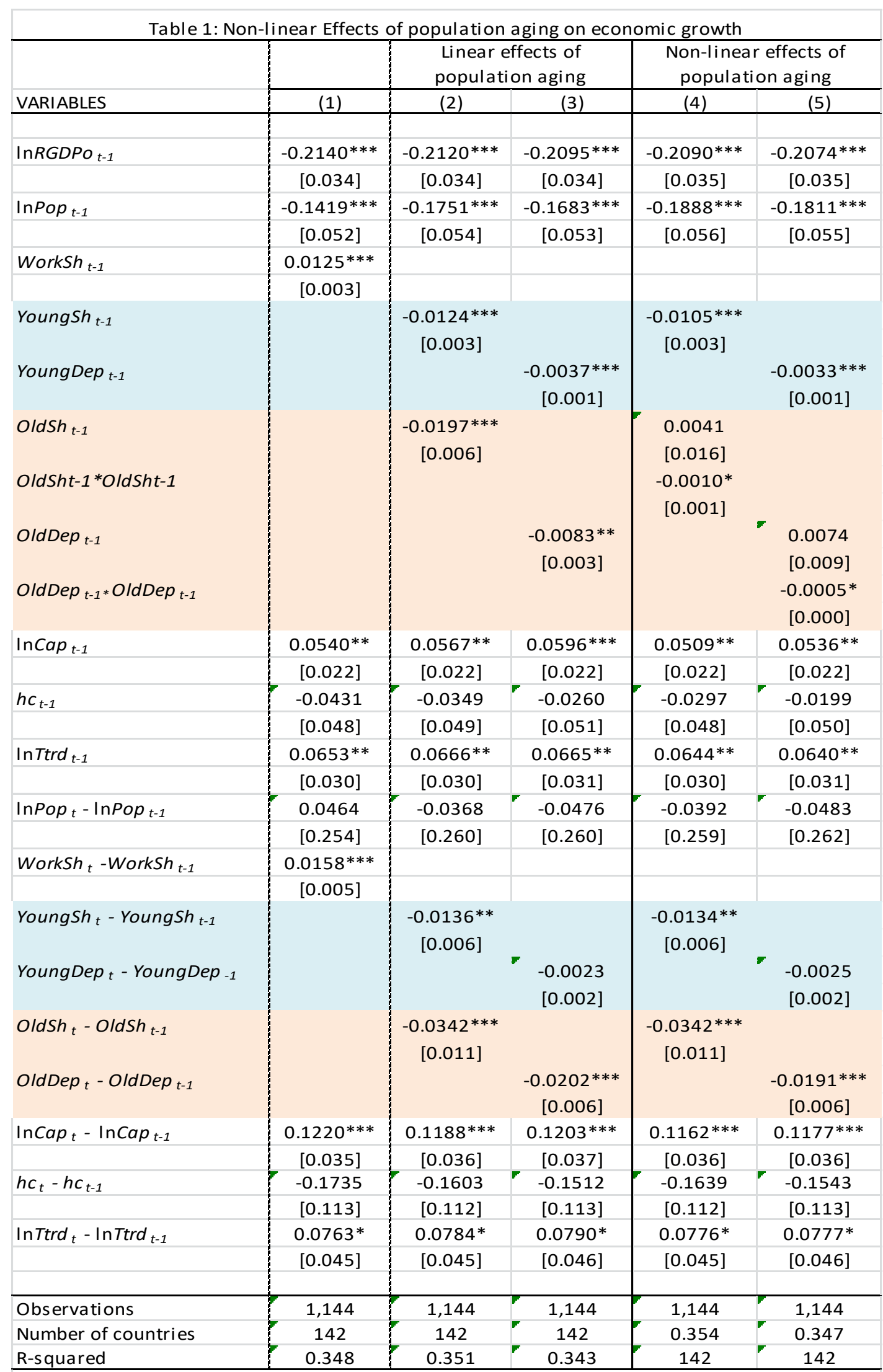

Notes: 1. Panel estimation with country-specific and period-specific effects. 2. Robust standard errors are in parentheses. $3 .{ }^{* *},{ }^{* *}$, and ${ }^{*}$ indicate the significance levels of 1,5 , and 10 percent, respectively.

Sources: Columns 1-3 are from Lee, Park, and Shin (2017). Other columns are from authors' calculations. 


\begin{tabular}{|c|c|c|c|c|c|c|}
\hline \multicolumn{7}{|c|}{ (A) Old-age population share (OId_Sh) } \\
\hline & \multirow[b]{2}{*}{$\mathrm{dy} / \mathrm{dx}$} & \multicolumn{2}{|c|}{ Delta-method } & \multirow[b]{2}{*}{$\mathrm{P}>\mathrm{z}$} & \multirow[b]{2}{*}{ [95\% Conf. } & \multirow[b]{2}{*}{ Interval] } \\
\hline & & Std. Err. & $z$ & & & \\
\hline \multicolumn{7}{|l|}{ L.old_sh } \\
\hline \multicolumn{7}{|l|}{ at } \\
\hline 1 & 0.002103 & 0.014869 & 0.14 & 0.888 & -0.02704 & 0.031246 \\
\hline 2 & 0.000138 & 0.013834 & 0.01 & 0.992 & -0.02698 & 0.027252 \\
\hline 3 & -0.00183 & 0.012816 & -0.14 & 0.887 & -0.02695 & 0.023291 \\
\hline 4 & -0.00379 & 0.011819 & -0.32 & 0.748 & -0.02696 & 0.019372 \\
\hline 5 & -0.00576 & 0.01085 & -0.53 & 0.596 & -0.02703 & 0.015508 \\
\hline 6 & -0.00772 & 0.009917 & -0.78 & 0.436 & -0.02716 & 0.011713 \\
\hline 7 & -0.00969 & 0.009031 & -1.07 & 0.283 & -0.02739 & 0.00801 \\
\hline 8 & -0.01166 & 0.008206 & -1.42 & 0.155 & -0.02774 & 0.004428 \\
\hline 9 & -0.01362 & 0.007463 & -1.83 & 0.068 & -0.02825 & 0.001007 \\
\hline 10 & -0.01559 & 0.00683 & -2.28 & 0.022 & -0.02897 & -0.0022 \\
\hline 11 & -0.01755 & 0.006339 & -2.77 & 0.006 & -0.02998 & -0.00513 \\
\hline 12 & -0.01952 & 0.006025 & -3.24 & 0.001 & -0.03133 & -0.00771 \\
\hline 13 & -0.02148 & 0.005916 & -3.63 & 0 & -0.03308 & -0.00989 \\
\hline 14 & -0.02345 & 0.006024 & -3.89 & 0 & -0.03525 & -0.01164 \\
\hline 15 & -0.02541 & 0.006336 & -4.01 & 0 & -0.03783 & -0.013 \\
\hline 16 & -0.02738 & 0.006826 & -4.01 & 0 & -0.04076 & -0.014 \\
\hline 17 & -0.02935 & 0.007459 & -3.93 & 0 & -0.04396 & -0.01473 \\
\hline 18 & -0.03131 & 0.0082 & -3.82 & 0 & -0.04738 & -0.01524 \\
\hline 19 & -0.03328 & 0.009025 & -3.69 & 0 & -0.05096 & -0.01559 \\
\hline 20 & -0.03524 & 0.009911 & -3.56 & 0 & -0.05467 & -0.01582 \\
\hline 21 & -0.03721 & 0.010844 & -3.43 & 0.001 & -0.05846 & -0.01595 \\
\hline 22 & -0.03917 & 0.011813 & -3.32 & 0.001 & -0.06232 & -0.01602 \\
\hline 23 & -0.04114 & 0.012809 & -3.21 & 0.001 & -0.06624 & -0.01603 \\
\hline 24 & -0.0431 & 0.013827 & -3.12 & 0.002 & -0.0702 & -0.016 \\
\hline 25 & -0.04507 & 0.014862 & -3.03 & 0.002 & -0.0742 & -0.01594 \\
\hline 26 & -0.04704 & 0.015911 & -2.96 & 0.003 & -0.07822 & -0.01585 \\
\hline 27 & -0.049 & 0.016971 & -2.89 & 0.004 & -0.08226 & -0.01574 \\
\hline 28 & -0.05097 & 0.018041 & -2.83 & 0.005 & -0.08633 & -0.01561 \\
\hline 29 & -0.05293 & 0.019118 & -2.77 & 0.006 & -0.0904 & -0.01546 \\
\hline 30 & -0.0549 & 0.020202 & -2.72 & 0.007 & -0.09449 & -0.0153 \\
\hline
\end{tabular}

Note: Calculated for Old-age population share (Old_Sh) in Column (3) of Table 1. 
(B) Old-age dependency ratio (Old_Dep)

\begin{tabular}{|c|c|c|c|c|c|c|}
\hline & \multirow[b]{2}{*}{$d y / d x$} & \multicolumn{2}{|c|}{ Delta-method } & \multirow[b]{2}{*}{$P>z$} & \multirow[b]{2}{*}{ [95\% Conf. } & \multirow[b]{2}{*}{ Interval] } \\
\hline & & Std. Err. & $z$ & & & \\
\hline \multicolumn{7}{|l|}{ L.old_dep } \\
\hline \multicolumn{7}{|l|}{ _at } \\
\hline 1 & 0.006451 & 0.008957 & 0.72 & 0.471 & -0.0111 & 0.024006 \\
\hline 2 & 0.005531 & 0.008515 & 0.65 & 0.516 & -0.01116 & 0.022221 \\
\hline 3 & 0.004611 & 0.008079 & 0.57 & 0.568 & -0.01122 & 0.020445 \\
\hline 4 & 0.003691 & 0.007647 & 0.48 & 0.629 & -0.0113 & 0.018679 \\
\hline 5 & 0.002771 & 0.007222 & 0.38 & 0.701 & -0.01138 & 0.016927 \\
\hline 6 & 0.001851 & 0.006805 & 0.27 & 0.786 & -0.01149 & 0.015189 \\
\hline 7 & 0.000931 & 0.006397 & 0.15 & 0.884 & -0.01161 & 0.013469 \\
\hline 8 & 1.07E-05 & 0.006 & 0 & 0.999 & -0.01175 & 0.011771 \\
\hline 9 & -0.00091 & 0.005617 & -0.16 & 0.871 & -0.01192 & 0.010099 \\
\hline 10 & -0.00183 & 0.00525 & -0.35 & 0.727 & -0.01212 & 0.00846 \\
\hline 11 & -0.00275 & 0.004902 & -0.56 & 0.575 & -0.01236 & 0.006859 \\
\hline 12 & -0.00367 & 0.00458 & -0.8 & 0.423 & -0.01265 & 0.005307 \\
\hline 13 & -0.00459 & 0.004287 & -1.07 & 0.284 & -0.01299 & 0.003813 \\
\hline 14 & -0.00551 & 0.004031 & -1.37 & 0.172 & -0.01341 & 0.002392 \\
\hline 15 & -0.00643 & 0.00382 & -1.68 & 0.092 & -0.01392 & 0.001057 \\
\hline 16 & -0.00735 & 0.00366 & -2.01 & 0.045 & -0.01452 & -0.00018 \\
\hline 17 & -0.00827 & 0.003558 & -2.32 & 0.02 & -0.01524 & -0.0013 \\
\hline 18 & -0.00919 & 0.003521 & -2.61 & 0.009 & -0.01609 & -0.00229 \\
\hline 19 & -0.01011 & 0.003549 & -2.85 & 0.004 & -0.01707 & -0.00315 \\
\hline 20 & -0.01103 & 0.003641 & -3.03 & 0.002 & -0.01817 & -0.00389 \\
\hline 21 & -0.01195 & 0.003793 & -3.15 & 0.002 & -0.01938 & -0.00452 \\
\hline 22 & -0.01287 & 0.003998 & -3.22 & 0.001 & -0.02071 & -0.00503 \\
\hline 23 & -0.01379 & 0.004248 & -3.25 & 0.001 & -0.02212 & -0.00546 \\
\hline 24 & -0.01471 & 0.004536 & -3.24 & 0.001 & -0.0236 & -0.00582 \\
\hline 25 & -0.01563 & 0.004854 & -3.22 & 0.001 & -0.02514 & -0.00612 \\
\hline 26 & -0.01655 & 0.005198 & -3.18 & 0.001 & -0.02674 & -0.00636 \\
\hline 27 & -0.01747 & 0.005563 & -3.14 & 0.002 & -0.02837 & -0.00657 \\
\hline 28 & -0.01839 & 0.005944 & -3.09 & 0.002 & -0.03004 & -0.00674 \\
\hline 29 & -0.01931 & 0.006339 & -3.05 & 0.002 & -0.03174 & -0.00689 \\
\hline 30 & -0.02023 & 0.006746 & -3 & 0.003 & -0.03345 & -0.00701 \\
\hline 31 & -0.02115 & 0.007162 & -2.95 & 0.003 & -0.03519 & -0.00711 \\
\hline 32 & -0.02207 & 0.007586 & -2.91 & 0.004 & -0.03694 & -0.0072 \\
\hline 33 & -0.02299 & 0.008016 & -2.87 & 0.004 & -0.0387 & -0.00728 \\
\hline 34 & -0.02391 & 0.008452 & -2.83 & 0.005 & -0.04048 & -0.00734 \\
\hline 35 & -0.02483 & 0.008893 & -2.79 & 0.005 & -0.04226 & -0.0074 \\
\hline 36 & -0.02575 & 0.009338 & -2.76 & 0.006 & -0.04405 & -0.00745 \\
\hline 37 & -0.02667 & 0.009787 & -2.73 & 0.006 & -0.04585 & -0.00749 \\
\hline 38 & -0.02759 & 0.010238 & -2.69 & 0.007 & -0.04766 & -0.00752 \\
\hline 39 & -0.02851 & 0.010693 & -2.67 & 0.008 & -0.04947 & -0.00755 \\
\hline 40 & -0.02943 & 0.011149 & -2.64 & 0.008 & -0.05128 & -0.00758 \\
\hline
\end{tabular}

Note: Calculated for Old-age dependency ratio (Old_Dep) in Column (4) of Table 1. Source: Authors' calculations. 
Table 3: Nonlinear specifications for old age population share

A. Young age population share included

\begin{tabular}{|c|c|c|c|c|c|c|}
\hline VARIABLES & (1) & (2) & (3) & (4) & (5) & (6) \\
\hline $\ln R G D P o_{t-1}$ & $\begin{array}{c}-0.1894^{* * *} \\
{[0.029]}\end{array}$ & $\begin{array}{c}-0.1808^{* * *} \\
{[0.030]}\end{array}$ & $\begin{array}{c}-0.2069 * * * \\
{[0.038]}\end{array}$ & $\begin{array}{c}-0.2089 * * * \\
{[0.028]}\end{array}$ & $\begin{array}{c}-0.2024^{* * *} \\
{[0.030]}\end{array}$ & $\begin{array}{c}-0.2108^{* * *} \\
{[0.036]}\end{array}$ \\
\hline $\ln P o p_{t-1}$ & $\begin{array}{c}-0.1216^{* *} \\
{[0.052]}\end{array}$ & $\begin{array}{c}-0.1337^{* *} \\
{[0.052]}\end{array}$ & $\begin{array}{c}-0.1937^{* * *} \\
{[0.061]}\end{array}$ & $\begin{array}{c}-0.1599 * * * \\
{[0.053]}\end{array}$ & $\begin{array}{c}-0.1649 * * * \\
{[0.049]}\end{array}$ & $\begin{array}{c}-0.1781^{* * *} \\
{[0.056]}\end{array}$ \\
\hline YoungSh $_{t-1}$ & $\begin{array}{l}-0.0083 \\
{[0.009]}\end{array}$ & $\begin{array}{l}-0.0072 \\
{[0.009]}\end{array}$ & $\begin{array}{l}-0.0095 \\
{[0.009]}\end{array}$ & $\begin{array}{c}-0.0178^{* *} \\
{[0.009]}\end{array}$ & $\begin{array}{l}-0.0155 \\
{[0.009]}\end{array}$ & $\begin{array}{c}-0.0209^{* *} \\
{[0.010]}\end{array}$ \\
\hline OldSh $_{t-1}$ & $\begin{array}{l}0.0022 \\
{[0.021]}\end{array}$ & $\begin{array}{l}0.0093 \\
{[0.015]}\end{array}$ & $\begin{array}{l}0.0040 \\
{[0.017]}\end{array}$ & $\begin{array}{l}0.0028 \\
{[0.018]}\end{array}$ & $\begin{array}{l}0.0079 \\
{[0.014]}\end{array}$ & $\begin{array}{l}0.0028 \\
{[0.016]}\end{array}$ \\
\hline YoungSht-1*YoungSht-1 & $\begin{array}{l}0.0000 \\
{[0.000]}\end{array}$ & $\begin{array}{l}-0.0000 \\
{[0.000]}\end{array}$ & $\begin{array}{l}-0.0000 \\
{[0.000]}\end{array}$ & $\begin{array}{l}0.0002 \\
{[0.000]}\end{array}$ & $\begin{array}{l}0.0001 \\
{[0.000]}\end{array}$ & $\begin{array}{l}0.0001 \\
{[0.000]}\end{array}$ \\
\hline OldSht-1*OldSht-1 & $\begin{array}{l}-0.0010 \\
{[0.001]}\end{array}$ & $\begin{array}{c}-0.0012^{* *} \\
{[0.001]}\end{array}$ & $\begin{array}{c}-0.0013^{* *} \\
{[0.001]}\end{array}$ & $\begin{array}{l}-0.0009 \\
{[0.001]}\end{array}$ & $\begin{array}{c}-0.0011^{* *} \\
{[0.001]}\end{array}$ & $\begin{array}{c}-0.0011^{*} \\
{[0.001]}\end{array}$ \\
\hline $\ln \operatorname{Cap}_{t-1}$ & $\begin{array}{l}0.0272 \\
{[0.029]}\end{array}$ & $\begin{array}{l}0.0167 \\
{[0.021]}\end{array}$ & $\begin{array}{l}0.0266 \\
{[0.023]}\end{array}$ & $\begin{array}{l}0.0507^{*} \\
{[0.030]}\end{array}$ & $\begin{array}{c}0.0448^{* *} \\
{[0.021]}\end{array}$ & $\begin{array}{c}0.0503^{* *} \\
{[0.022]}\end{array}$ \\
\hline$h c_{t-1}$ & & $\begin{array}{l}-0.0329 \\
{[0.043]}\end{array}$ & $\begin{array}{l}-0.0112 \\
{[0.048]}\end{array}$ & & $\begin{array}{l}-0.0330 \\
{[0.045]}\end{array}$ & $\begin{array}{l}-0.0284 \\
{[0.048]}\end{array}$ \\
\hline $\ln T t r d_{t-1}$ & & & $\begin{array}{l}0.0361 \\
{[0.030]}\end{array}$ & & & $\begin{array}{c}0.0651^{* *} \\
{[0.030]}\end{array}$ \\
\hline $\ln P o p_{t}-\ln P o p_{t-1}$ & & & & $\begin{array}{l}-0.2229 \\
{[0.229]}\end{array}$ & $\begin{array}{l}-0.0302 \\
{[0.316]}\end{array}$ & $\begin{array}{l}-0.0832 \\
{[0.275]}\end{array}$ \\
\hline YoungSh $_{t}-$ YoungSh $_{t-1}$ & & & & $\begin{array}{c}-0.0095^{*} \\
{[0.005]}\end{array}$ & $\begin{array}{c}-0.0119 * * \\
{[0.005]}\end{array}$ & $\begin{array}{c}-0.0148^{* *} \\
{[0.006]}\end{array}$ \\
\hline OldSh $_{t}-$ OldSh $_{t-1}$ & & & & $\begin{array}{l}-0.0197 \\
{[0.014]}\end{array}$ & $\begin{array}{c}-0.0267^{* *} \\
{[0.011]}\end{array}$ & $\begin{array}{c}-0.0364^{* * *} \\
{[0.011]}\end{array}$ \\
\hline $\ln C a p_{t}-\operatorname{InCap} p_{t-1}$ & & & & $\begin{array}{c}0.1730 * * * \\
{[0.048]}\end{array}$ & $\begin{array}{c}0.1440^{* * *} \\
{[0.036]}\end{array}$ & $\begin{array}{c}0.1170^{* * *} \\
{[0.036]}\end{array}$ \\
\hline$h c_{t}-h c_{t-1}$ & & & & & $\begin{array}{l}-0.0294 \\
{[0.110]}\end{array}$ & $\begin{array}{l}-0.1588 \\
{[0.112]}\end{array}$ \\
\hline $\ln T t r d_{t}-\ln T t r d_{t-1}$ & & & & & & $\begin{array}{c}0.0785^{*} \\
{[0.045]}\end{array}$ \\
\hline Observations & 1,489 & 1,293 & 1,150 & 1,489 & 1,293 & 1,144 \\
\hline Number of countries & 170 & 143 & 142 & 170 & 143 & 142 \\
\hline R-squared & 0.231 & 0.262 & 0.294 & 0.285 & 0.309 & 0.356 \\
\hline
\end{tabular}

Notes: 1. The dependent variable is five-year growth rate of per capita GDP. 2. Panel estimation with country-specific and period-specific effects. 3 . Robust standard errors are in parentheses. $4 .{ }^{* * *},{ }^{* *}$, and $*$ indicate the significance levels of 1,5 , and 10 percent, respectively.

Source: Authors' calculations. 
B. Young age population share excluded

\begin{tabular}{|c|c|c|c|c|c|c|}
\hline VARIABLES & (1) & $(2)$ & (3) & (4) & (5) & (6) \\
\hline $\ln R G D P o_{t-1}$ & $\begin{array}{c}-0.1774 * * * \\
{[0.028]}\end{array}$ & $\begin{array}{c}-0.1677^{* * *} \\
{[0.030]}\end{array}$ & $\begin{array}{c}-0.1930 * * * \\
{[0.038]}\end{array}$ & $\begin{array}{c}-0.1950 * * * \\
{[0.027]}\end{array}$ & $\begin{array}{c}-0.1877 * * * \\
{[0.030]}\end{array}$ & $\begin{array}{c}-0.1959 * * * \\
{[0.035]}\end{array}$ \\
\hline $\ln P_{o p} p_{t-1}$ & $\begin{array}{c}-0.1192 * * \\
{[0.052]}\end{array}$ & $\begin{array}{c}-0.1297^{* *} \\
{[0.055]}\end{array}$ & $\begin{array}{c}-0.1995 * * * \\
{[0.059]}\end{array}$ & $\begin{array}{c}-0.1552 * * * \\
{[0.052]}\end{array}$ & $\begin{array}{c}-0.1601 * * * \\
{[0.050]}\end{array}$ & $\begin{array}{c}-0.1961 * * * \\
{[0.056]}\end{array}$ \\
\hline OldSh $_{t-1}$ & $\begin{array}{l}0.0268 \\
{[0.020]}\end{array}$ & $\begin{array}{c}0.0397 * * * \\
{[0.013]}\end{array}$ & $\begin{array}{c}0.0387 * * * \\
{[0.014]}\end{array}$ & $\begin{array}{l}0.0238 \\
{[0.017]}\end{array}$ & $\begin{array}{c}0.0377^{* * *} \\
{[0.013]}\end{array}$ & $\begin{array}{c}0.0340 * * \\
{[0.014]}\end{array}$ \\
\hline OldSht-1*OldSht-1 & $\begin{array}{c}-0.0017^{* *} \\
{[0.001]}\end{array}$ & $\begin{array}{c}-0.0022 * * * \\
{[0.000]}\end{array}$ & $\begin{array}{c}-0.0024^{* * *} \\
{[0.001]}\end{array}$ & $\begin{array}{c}-0.0014^{* *} \\
{[0.001]}\end{array}$ & $\begin{array}{c}-0.0020 * * * \\
{[0.000]}\end{array}$ & $\begin{array}{c}-0.0021 * * * \\
{[0.001]}\end{array}$ \\
\hline $\ln \operatorname{Cap}_{t-1}$ & $\begin{array}{l}0.0254 \\
{[0.028]}\end{array}$ & $\begin{array}{l}0.0121 \\
{[0.021]}\end{array}$ & $\begin{array}{l}0.0222 \\
{[0.024]}\end{array}$ & $\begin{array}{c}0.0499 * \\
{[0.028]}\end{array}$ & $\begin{array}{c}0.0422 * * \\
{[0.021]}\end{array}$ & $\begin{array}{c}0.0505^{* *} \\
{[0.023]}\end{array}$ \\
\hline$h c_{t-1}$ & & $\begin{array}{l}0.0370 \\
{[0.042]}\end{array}$ & $\begin{array}{l}0.0634 \\
{[0.048]}\end{array}$ & & $\begin{array}{l}0.0407 \\
{[0.045]}\end{array}$ & $\begin{array}{l}0.0383 \\
{[0.048]}\end{array}$ \\
\hline $\ln \operatorname{Ttrd}_{t-1}$ & & & $\begin{array}{l}0.0360 \\
{[0.032]}\end{array}$ & & & $\begin{array}{c}0.0643 * * \\
{[0.032]}\end{array}$ \\
\hline $\ln P o p_{t}-\ln P o p_{t-1}$ & & & & $\begin{array}{l}-0.2888 \\
{[0.202]}\end{array}$ & $\begin{array}{l}-0.1412 \\
{[0.268]}\end{array}$ & $\begin{array}{l}-0.2704 \\
{[0.240]}\end{array}$ \\
\hline$O l d S h_{t}-O l d S h_{t-1}$ & & & & $\begin{array}{l}-0.0116 \\
{[0.013]}\end{array}$ & $\begin{array}{l}-0.0167 \\
{[0.011]}\end{array}$ & $\begin{array}{c}-0.0245^{* *} \\
{[0.011]}\end{array}$ \\
\hline $\ln C a p_{t}-\ln C a p_{t-1}$ & & & & $\begin{array}{c}0.1727 * * * \\
{[0.047]}\end{array}$ & $\begin{array}{c}0.1444 * * * \\
{[0.037]}\end{array}$ & $\begin{array}{c}0.1200 * * * \\
{[0.038]}\end{array}$ \\
\hline$h c_{t}-h c_{t-1}$ & & & & & $\begin{array}{l}-0.0015 \\
{[0.106]}\end{array}$ & $\begin{array}{l}-0.1057 \\
{[0.115]}\end{array}$ \\
\hline $\ln T t r d_{t}-\ln T t r d_{t-1}$ & & & & & & $\begin{array}{c}0.0828^{*} \\
{[0.046]}\end{array}$ \\
\hline $\begin{array}{l}\text { Observations } \\
\text { Number of } \\
\text { countries }\end{array}$ & 1,489 & 1,293 & 1,150 & 1,489 & 1,293 & 1,144 \\
\hline R-squared & 0.223 & 0.249 & 0.277 & 0.274 & 0.287 & 0.330 \\
\hline
\end{tabular}

Notes: 1 . The dependent variable is five-year growth rate of per capita GDP. 2. Panel estimation with country-specific and period-specific effects. 3. Robust standard errors are in parentheses. 4. ***, **, and $*$ indicate the significance levels of 1,5 , and 10 percent, respectively.

Source: Authors' calculations. 
Table 4: Nonlinear specifications for working-age population share

\begin{tabular}{|c|c|c|c|c|c|c|}
\hline VARIABLES & $(1)$ & $(2)$ & (3) & (4) & (5) & (6) \\
\hline $\ln R G D P o_{t-1}$ & $\begin{array}{c}-0.1931 * * * \\
{[0.028]}\end{array}$ & $\begin{array}{c}-0.1829 * * * \\
{[0.030]}\end{array}$ & $\begin{array}{c}-0.2121 * * * \\
{[0.037]}\end{array}$ & $\begin{array}{c}-0.2126 * * * \\
{[0.028]}\end{array}$ & $\begin{array}{c}-0.2051 * * * \\
{[0.029]}\end{array}$ & $\begin{array}{c}-0.2160 * * * \\
{[0.035]}\end{array}$ \\
\hline $\ln$ Pop $_{t-1}$ & $\begin{array}{l}-0.0623 \\
{[0.046]}\end{array}$ & $\begin{array}{c}-0.0745^{*} \\
{[0.044]}\end{array}$ & $\begin{array}{c}-0.0894^{*} \\
{[0.052]}\end{array}$ & $\begin{array}{c}-0.1370 * * * \\
{[0.046]}\end{array}$ & $\begin{array}{c}-0.1473 * * * \\
{[0.044]}\end{array}$ & $\begin{array}{c}-0.1336^{* *} \\
{[0.052]}\end{array}$ \\
\hline WorkSht-1 & $\begin{array}{l}0.0020 \\
{[0.020]}\end{array}$ & $\begin{array}{l}0.0116 \\
{[0.020]}\end{array}$ & $\begin{array}{c}-0.0008 \\
{[0.019]}\end{array}$ & $\begin{array}{l}-0.0179 \\
{[0.020]}\end{array}$ & $\begin{array}{l}-0.0013 \\
{[0.021]}\end{array}$ & $\begin{array}{l}-0.0219 \\
{[0.021]}\end{array}$ \\
\hline WorkSht-1*WorkSht-1 & $\begin{array}{l}0.0000 \\
{[0.000]}\end{array}$ & $\begin{array}{l}-0.0000 \\
{[0.000]}\end{array}$ & $\begin{array}{l}0.0001 \\
{[0.000]}\end{array}$ & $\begin{array}{l}0.0002 \\
{[0.000]}\end{array}$ & $\begin{array}{l}0.0001 \\
{[0.000]}\end{array}$ & $\begin{array}{c}0.0003^{*} \\
{[0.000]}\end{array}$ \\
\hline $\ln \operatorname{Cap}_{t-1}$ & $\begin{array}{l}0.0294 \\
{[0.026]}\end{array}$ & $\begin{array}{l}0.0206 \\
{[0.021]}\end{array}$ & $\begin{array}{l}0.0282 \\
{[0.023]}\end{array}$ & $\begin{array}{c}0.0529 * \\
{[0.028]}\end{array}$ & $\begin{array}{c}0.0486 * * \\
{[0.020]}\end{array}$ & $\begin{array}{c}0.0514^{* *} \\
{[0.022]}\end{array}$ \\
\hline$h c_{t-1}$ & & $\begin{array}{l}-0.0594 \\
{[0.042]}\end{array}$ & $\begin{array}{l}-0.0303 \\
{[0.048]}\end{array}$ & & $\begin{array}{l}-0.0492 \\
{[0.045]}\end{array}$ & $\begin{array}{l}-0.0406 \\
{[0.048]}\end{array}$ \\
\hline $\ln T t r d_{t-1}$ & & & $\begin{array}{l}0.0379 \\
{[0.031]}\end{array}$ & & & $\begin{array}{c}0.0663^{* *} \\
{[0.030]}\end{array}$ \\
\hline $\ln P_{o p_{t}}-\ln P_{o p_{t-1}}$ & & & & $\begin{array}{l}-0.1734 \\
{[0.214]}\end{array}$ & $\begin{array}{l}0.0073 \\
{[0.305]}\end{array}$ & $\begin{array}{l}-0.0210 \\
{[0.278]}\end{array}$ \\
\hline WorkSh $_{t}-$ WorkSh $_{t-1}$ & & & & $\begin{array}{c}0.0107^{* *} \\
{[0.005]}\end{array}$ & $\begin{array}{c}0.0131 * * * \\
{[0.005]}\end{array}$ & $\begin{array}{c}0.0178^{* * *} \\
{[0.006]}\end{array}$ \\
\hline $\ln C a p_{t}-\operatorname{In} C a p_{t-1}$ & & & & $\begin{array}{c}0.1782 * * * \\
{[0.048]}\end{array}$ & $\begin{array}{c}0.1492 * * * \\
{[0.036]}\end{array}$ & $\begin{array}{c}0.1231^{* * *} \\
{[0.036]}\end{array}$ \\
\hline$h c_{t}-h c_{t-1}$ & & & & & $\begin{array}{l}-0.0245 \\
{[0.112]}\end{array}$ & $\begin{array}{l}-0.1668 \\
{[0.112]}\end{array}$ \\
\hline $\ln T t r d_{t}-\ln T t r d_{t-1}$ & & & & & & $\begin{array}{c}0.0777^{*} \\
{[0.045]}\end{array}$ \\
\hline Observations & 1,489 & 1,293 & 1,150 & 1,489 & 1,293 & 1,144 \\
\hline Number of countries & 170 & 143 & 142 & 170 & 143 & 142 \\
\hline R-squared & 0.225 & 0.254 & 0.284 & 0.283 & 0.305 & 0.352 \\
\hline
\end{tabular}

Notes: 1. The dependent variable is five-year growth rate of per capita GDP. 2. Panel estimation with country-specific and period-specific effects. 3. Robust standard errors are in parentheses. 4. $* * *, * *$, and * indicate the significance levels of 1,5 , and 10 percent, respectively.

Source: Authors' calculations. 
Table 5: Nonlinear relationship between working-age population share and old/young population share A. Level specification

\begin{tabular}{|c|c|c|c|c|c|c|}
\hline VARIABLES & (1) & $(2)$ & (3) & $(4)$ & (5) & (6) \\
\hline OldSh $_{t-1}$ & $\begin{array}{c}2.6185^{* * *} \\
{[0.163]}\end{array}$ & $\begin{array}{c}3.9380 * * * \\
{[0.256]}\end{array}$ & $\begin{array}{c}4.8506 * * * \\
{[0.278]}\end{array}$ & & & \\
\hline OldSht- $1 *$ OldSht-1 & $\begin{array}{c}-0.0854 * * * \\
{[0.008]}\end{array}$ & $\begin{array}{c}-0.1340 * * * \\
{[0.010]}\end{array}$ & $\begin{array}{c}-0.1618^{* * *} \\
{[0.010]}\end{array}$ & & & \\
\hline YoungSh $_{t-1}$ & & & & $\begin{array}{c}0.1994 * * * \\
{[0.052]}\end{array}$ & $\begin{array}{l}-0.0756 \\
{[0.089]}\end{array}$ & $\begin{array}{l}-0.1188 \\
{[0.092]}\end{array}$ \\
\hline YoungSht-1*YoungSht-1 & & & & $\begin{array}{c}-0.0129 * * * \\
{[0.001]}\end{array}$ & $\begin{array}{c}-0.0106 * * * \\
{[0.001]}\end{array}$ & $\begin{array}{c}-0.0103 * * * \\
{[0.001]}\end{array}$ \\
\hline Observations & 1,663 & 1,663 & 1,663 & 1,663 & 1,663 & 1,663 \\
\hline Number of countries & & 171 & 171 & & 171 & 171 \\
\hline R-squared & 0.502 & 0.502 & 0.432 & 0.931 & 0.928 & 0.956 \\
\hline \multicolumn{7}{|l|}{ B. Difference specification } \\
\hline VARIABLES & (1) & $(2)$ & (3) & $(4)$ & $(5)$ & (6) \\
\hline OldSht - OldSht-1 & $\begin{array}{c}0.5762 * * * \\
{[0.147]}\end{array}$ & $\begin{array}{c}0.4301 * * \\
{[0.201]}\end{array}$ & $\begin{array}{l}0.4095^{*} \\
{[0.230]}\end{array}$ & & & \\
\hline (OldSht - OldSht-1)*(OldSht - OldSht-1) & $\begin{array}{c}-0.5174 * * * \\
{[0.074]}\end{array}$ & $\begin{array}{c}-0.4643^{* * *} \\
{[0.093]}\end{array}$ & $\begin{array}{c}-0.4575 * * * \\
{[0.101]}\end{array}$ & & & \\
\hline YoungSht - YoungSht-1 & & & & $\begin{array}{c}-0.8484 * * * \\
{[0.012]}\end{array}$ & $\begin{array}{c}-0.9268 * * * \\
{[0.015]}\end{array}$ & $\begin{array}{c}-0.9414 * * * \\
{[0.016]}\end{array}$ \\
\hline $\begin{array}{l}\text { (YoungSht - YoungSht-1)*(YoungSht - } \\
\text { YoungSht-1) }\end{array}$ & & & & $\begin{array}{c}0.0176 * * * \\
{[0.003]}\end{array}$ & $\begin{array}{l}0.0020 \\
{[0.003]}\end{array}$ & $\begin{array}{l}-0.0010 \\
{[0.004]}\end{array}$ \\
\hline Observations & 1,492 & 1,492 & 1,492 & 1,492 & 1,492 & 1,492 \\
\hline Number of countries & & 171 & 171 & & 171 & 171 \\
\hline R-squared & 0.027 & 0.027 & 0.024 & 0.890 & 0.888 & 0.923 \\
\hline
\end{tabular}

Notes: 1. The dependent variable is working-age population share (panel A) and its five-year difference (panel B). 2. Columns (1) and (4) are pooling OLS estimation, columns (2) and (5) are panel estimation with random effects and columns (3) and (6) are panel estimation with country-specific and period-specific effects. 3. Robust standard errors are in parentheses. $4 . * * *, * *$, and * indicate the significance levels of 1,5, and 10 percent, respectively.

Source: Authors' calculations. 
Table 6: Stronger effects of population aging on economic growth in recent years

\begin{tabular}{|c|c|c|c|c|c|c|}
\hline \multirow[b]{2}{*}{ VARIABLES } & \multicolumn{2}{|c|}{ Whole sample } & \multicolumn{2}{|c|}{ Before 2010} & \multicolumn{2}{|c|}{ Whole sample } \\
\hline & (1) & $(2)$ & (3) & (4) & (5) & (6) \\
\hline $\ln R G D P o_{t-1}$ & $\begin{array}{c}-0.2120 * * * \\
{[0.034]}\end{array}$ & $\begin{array}{c}-0.2095 * * * \\
{[0.034]}\end{array}$ & $\begin{array}{c}-0.1777 * * * \\
{[0.049]}\end{array}$ & $\begin{array}{c}-0.1748 * * * \\
{[0.048]}\end{array}$ & $\begin{array}{c}-0.1924 * * * \\
{[0.036]}\end{array}$ & $\begin{array}{c}-0.1886 * * * \\
{[0.035]}\end{array}$ \\
\hline $\ln P_{o p} p_{t-1}$ & $\begin{array}{c}-0.1751 * * * \\
{[0.054]}\end{array}$ & $\begin{array}{c}-0.1683 * * * \\
{[0.053]}\end{array}$ & $\begin{array}{c}-0.1680 * \\
{[0.100]}\end{array}$ & $\begin{array}{c}-0.1642 * \\
{[0.093]}\end{array}$ & $\begin{array}{c}-0.3060 * * * \\
{[0.075]}\end{array}$ & $\begin{array}{c}-0.3177 * * * \\
{[0.077]}\end{array}$ \\
\hline YoungSh $_{t-1}$ & $\begin{array}{c}-0.0124 * * * \\
{[0.003]}\end{array}$ & & $\begin{array}{c}-0.0121 * * * \\
{[0.003]}\end{array}$ & & $\begin{array}{c}-0.0096 * * * \\
{[0.003]}\end{array}$ & \\
\hline YoungDep $_{t-1}$ & & $\begin{array}{c}-0.0037^{* * *} \\
{[0.001]}\end{array}$ & & $\begin{array}{c}-0.0034 * * \\
{[0.001]}\end{array}$ & & $\begin{array}{c}-0.0027^{* * *} \\
{[0.001]}\end{array}$ \\
\hline OldSh $_{t-1}$ & $\begin{array}{c}-0.0197 * * * \\
{[0.006]}\end{array}$ & & $\begin{array}{l}-0.0137 \\
{[0.011]}\end{array}$ & & $\begin{array}{c}0.0033 \\
{[0.010]}\end{array}$ & \\
\hline OldSht-1*Period & & & & & $\begin{array}{c}-0.0024 * * * \\
{[0.001]}\end{array}$ & \\
\hline OldDep $p_{t-1}$ & & $\begin{array}{c}-0.0083^{* *} \\
{[0.003]}\end{array}$ & & $\begin{array}{l}-0.0037 \\
{[0.007]}\end{array}$ & & $\begin{array}{l}0.0060 \\
{[0.005]}\end{array}$ \\
\hline OldDep $p_{t-1} *$ Period & & & & & & $\begin{array}{c}-0.0018 * * * \\
{[0.001]}\end{array}$ \\
\hline $\ln \operatorname{Cap}_{t-1}$ & $\begin{array}{c}0.0567 * * \\
{[0.022]}\end{array}$ & $\begin{array}{c}0.0596 * * * \\
{[0.022]}\end{array}$ & $\begin{array}{c}-0.0039 \\
{[0.039]}\end{array}$ & $\begin{array}{c}-0.0033 \\
{[0.039]}\end{array}$ & $\begin{array}{c}0.0396 * \\
{[0.024]}\end{array}$ & $\begin{array}{c}0.0402 * \\
{[0.024]}\end{array}$ \\
\hline$h c_{t-1}$ & $\begin{array}{l}-0.0349 \\
{[0.049]}\end{array}$ & $\begin{array}{l}-0.0260 \\
{[0.051]}\end{array}$ & $\begin{array}{l}0.0154 \\
{[0.068]}\end{array}$ & $\begin{array}{l}0.0242 \\
{[0.069]}\end{array}$ & $\begin{array}{l}-0.0155 \\
{[0.045]}\end{array}$ & $\begin{array}{l}-0.0058 \\
{[0.046]}\end{array}$ \\
\hline $\ln T t r d_{t-1}$ & $\begin{array}{c}0.0666 * * \\
{[0.030]}\end{array}$ & $\begin{array}{c}0.0665^{* *} \\
{[0.031]}\end{array}$ & $\begin{array}{c}0.0981 * * * \\
{[0.029]}\end{array}$ & $\begin{array}{c}0.0993 * * * \\
{[0.030]}\end{array}$ & $\begin{array}{c}0.0652 * * \\
{[0.029]}\end{array}$ & $\begin{array}{c}0.0653 * * \\
{[0.030]}\end{array}$ \\
\hline $\ln P o p_{t}-\ln P_{o p_{t-1}}$ & $\begin{array}{c}-0.0368 \\
{[0.260]}\end{array}$ & $\begin{array}{l}-0.0476 \\
{[0.260]}\end{array}$ & $\begin{array}{l}-0.3815 \\
{[0.504]}\end{array}$ & $\begin{array}{c}-0.4468 \\
{[0.510]}\end{array}$ & $\begin{array}{l}-0.0687 \\
{[0.258]}\end{array}$ & $\begin{array}{l}-0.0916 \\
{[0.266]}\end{array}$ \\
\hline YoungSh $_{t}-$ YoungSh $_{t-1}$ & $\begin{array}{c}-0.0136^{* *} \\
{[0.006]}\end{array}$ & & $\begin{array}{l}-0.0087 \\
{[0.007]}\end{array}$ & & $\begin{array}{c}-0.0125^{* *} \\
{[0.006]}\end{array}$ & \\
\hline YoungDep $_{t}-$ YoungDep $_{-1}$ & & $\begin{array}{l}-0.0023 \\
{[0.002]}\end{array}$ & & $\begin{array}{l}-0.0010 \\
{[0.003]}\end{array}$ & & $\begin{array}{c}-0.0024 \\
{[0.002]}\end{array}$ \\
\hline$O l d S h_{t}-O l d S h_{t-1}$ & $\begin{array}{c}-0.0342 * * * \\
{[0.011]}\end{array}$ & & $\begin{array}{c}-0.0160 \\
{[0.017]}\end{array}$ & & $\begin{array}{c}-0.0325 * * * \\
{[0.011]}\end{array}$ & \\
\hline OldDep $_{t}-$ OldDep $_{t-1}$ & & $\begin{array}{c}-0.0202 * * * \\
{[0.006]}\end{array}$ & & $\begin{array}{l}-0.0073 \\
{[0.011]}\end{array}$ & & $\begin{array}{c}-0.0182 * * * \\
{[0.006]}\end{array}$ \\
\hline $\ln C a p_{t}-\operatorname{In} C a p_{t-1}$ & $\begin{array}{c}0.1188^{* * *} \\
{[0.036]}\end{array}$ & $\begin{array}{c}0.1203 * * * \\
{[0.037]}\end{array}$ & $\begin{array}{c}0.1780 * * \\
{[0.071]}\end{array}$ & $\begin{array}{c}0.1789 * * \\
{[0.072]}\end{array}$ & $\begin{array}{c}0.1061 * * * \\
{[0.037]}\end{array}$ & $\begin{array}{c}0.1061 * * * \\
{[0.037]}\end{array}$ \\
\hline$h c_{t}-h c_{t-1}$ & $\begin{array}{l}-0.1603 \\
{[0.112]}\end{array}$ & $\begin{array}{l}-0.1512 \\
{[0.113]}\end{array}$ & $\begin{array}{l}-0.1143 \\
{[0.175]}\end{array}$ & $\begin{array}{l}-0.1037 \\
{[0.172]}\end{array}$ & $\begin{array}{l}-0.1466 \\
{[0.113]}\end{array}$ & $\begin{array}{l}-0.1363 \\
{[0.114]}\end{array}$ \\
\hline $\ln T t r d_{t}-\ln T t r d_{t-1}$ & $\begin{array}{c}0.0784^{*} \\
{[0.045]}\end{array}$ & $\begin{array}{c}0.0790 * \\
{[0.046]}\end{array}$ & $\begin{array}{c}0.1241 * * * \\
{[0.045]}\end{array}$ & $\begin{array}{c}0.1257^{* * *} \\
{[0.045]}\end{array}$ & $\begin{array}{c}0.0787^{*} \\
{[0.045]}\end{array}$ & $\begin{array}{c}0.0798 * \\
{[0.045]}\end{array}$ \\
\hline Observations & 1,144 & 1,144 & 725 & 725 & 1,144 & 1,144 \\
\hline Number of countries & 142 & 142 & 134 & 134 & 142 & 142 \\
\hline R-squared & 0.351 & 0.343 & 0.369 & 0.365 & 0.359 & 0.354 \\
\hline
\end{tabular}

Notes: 1. Panel estimation with country-specific and period-specific effects. 2. Robust standard errors are in 
parentheses. $3 .{ }^{* * *}, * *$, and $*$ indicate the significance levels of 1,5 , and 10 percent, respectively.

Source: Authors' calculations 
Table 7: Average marginal effects of population aging on economic growth at different periods of time

(A) Old-age population share (Old_Sh)

\begin{tabular}{rrrrrrr}
\hline \multicolumn{7}{c}{ Delta-method } \\
\hline \multicolumn{7}{c}{ L.old_sh } \\
_at & & Std. Err. & \multicolumn{1}{c}{$z$} & $\mathrm{P}>\mathrm{z}$ & {$[95 \%$ Conf. } & Interval] \\
\hline 1 & 0.000846 & 0.008956 & 0.09 & 0.925 & -0.01671 & 0.018399 \\
2 & -0.00156 & 0.008289 & -0.19 & 0.851 & -0.01781 & 0.014684 \\
3 & -0.00397 & 0.007662 & -0.52 & 0.604 & -0.01899 & 0.011046 \\
4 & -0.00638 & 0.007085 & -0.9 & 0.368 & -0.02026 & 0.007508 \\
5 & -0.00879 & 0.006572 & -1.34 & 0.181 & -0.02167 & 0.004094 \\
6 & -0.01119 & 0.006138 & -1.82 & 0.068 & -0.02322 & 0.000837 \\
7 & -0.0136 & 0.005802 & -2.34 & 0.019 & -0.02497 & -0.00223 \\
8 & -0.01601 & 0.005582 & -2.87 & 0.004 & -0.02695 & -0.00507 \\
9 & -0.01842 & 0.00549 & -3.35 & 0.001 & -0.02918 & -0.00766 \\
10 & -0.02083 & 0.005534 & -3.76 & 0 & -0.03167 & -0.00998 \\
11 & -0.02323 & 0.005711 & -4.07 & 0 & -0.03443 & -0.01204 \\
\hline
\end{tabular}

Note: Calculated for Old-age population share (Old_Sh) in Column (5) of Table 6.

(B) Old-age dependency ratio (Old Dep)

\begin{tabular}{|c|c|c|c|c|c|c|}
\hline & \multicolumn{4}{|c|}{ Delta-method } & \\
\hline & $d y / d x$ & Std. Err. & z & $P>z$ & $\begin{array}{l}{[95 \%} \\
\text { Conf. }\end{array}$ & Interval] \\
\hline \multicolumn{7}{|l|}{ L.old_dep } \\
\hline \multicolumn{7}{|l|}{ _at } \\
\hline 1 & 0.00425 & 0.004841 & 0.88 & 0.38 & -0.00524 & 0.013738 \\
\hline 2 & 0.002465 & 0.004452 & 0.55 & 0.58 & -0.00626 & 0.011191 \\
\hline 3 & 0.000681 & 0.004099 & 0.17 & 0.868 & -0.00735 & 0.008716 \\
\hline 4 & -0.0011 & 0.003794 & -0.29 & 0.771 & -0.00854 & 0.006332 \\
\hline 5 & -0.00289 & 0.003548 & -0.81 & 0.416 & -0.00984 & 0.004065 \\
\hline 6 & -0.00467 & 0.003374 & -1.39 & 0.166 & -0.01129 & 0.00194 \\
\hline 7 & -0.00646 & 0.003283 & -1.97 & 0.049 & -0.01289 & $-2.2 \mathrm{E}-05$ \\
\hline 8 & -0.00824 & 0.003283 & -2.51 & 0.012 & -0.01468 & -0.00181 \\
\hline 9 & -0.01003 & 0.003374 & -2.97 & 0.003 & -0.01664 & -0.00341 \\
\hline 10 & -0.01181 & 0.003548 & -3.33 & 0.001 & -0.01876 & -0.00486 \\
\hline 11 & -0.0136 & 0.003794 & -3.58 & 0 & -0.02103 & -0.00616 \\
\hline
\end{tabular}

Note: Calculated for Old-age population share (Old_Sh) in Column (6) of Table 6.

source: Authors' calculations 
Table 8: Stronger Negative Effects of population aging in developed countries

\begin{tabular}{|c|c|c|c|c|}
\hline \multirow[t]{2}{*}{ VARIABLES } & \multicolumn{2}{|c|}{ OECD countries } & \multicolumn{2}{|c|}{ Non-OECD countries } \\
\hline & (1) & $(2)$ & (3) & (4) \\
\hline \multirow[t]{2}{*}{$\ln R G D P o_{t-1}$} & $-0.0811^{*}$ & $-0.0832 *$ & $-0.2070 * * *$ & $-0.2041 * * *$ \\
\hline & {$[0.044]$} & {$[0.045]$} & {$[0.040]$} & {$[0.040]$} \\
\hline \multirow[t]{2}{*}{$\ln P o p_{t-1}$} & -0.1129 & -0.1092 & $-0.2046 * * *$ & $-0.1959 * *$ \\
\hline & [0.084] & {$[0.090]$} & {$[0.076]$} & {$[0.076]$} \\
\hline \multirow{2}{*}{ YoungSh $_{t-1}$} & $-0.0071^{*}$ & & $-0.0108 * * *$ & \\
\hline & {$[0.004]$} & & [0.003] & \\
\hline \multirow[t]{2}{*}{ YoungDep $_{t-1}$} & & -0.0019 & & $-0.0032 * * *$ \\
\hline & & {$[0.002]$} & & [0.001] \\
\hline \multirow[t]{2}{*}{ OldSh $_{t-1}$} & $-0.0126 * * *$ & & $-0.0170^{*}$ & \\
\hline & [0.004] & & {$[0.010]$} & \\
\hline \multirow[t]{2}{*}{ OldDep $_{t-1}$} & & $-0.0063 * * *$ & & -0.0057 \\
\hline & & {$[0.002]$} & & {$[0.006]$} \\
\hline \multirow[t]{2}{*}{$\ln \operatorname{Cap}_{t-1}$} & -0.0091 & -0.0010 & $0.0455^{*}$ & $0.0463 *$ \\
\hline & [0.039] & {$[0.042]$} & {$[0.026]$} & {$[0.026]$} \\
\hline \multirow[t]{2}{*}{$h c_{t-1}$} & -0.0378 & -0.0289 & -0.0408 & -0.0346 \\
\hline & [0.059] & {$[0.061]$} & {$[0.057]$} & {$[0.057]$} \\
\hline \multirow[t]{2}{*}{$\ln T t r d_{t-1}$} & 0.0314 & 0.0301 & $0.0766^{* *}$ & $0.0755^{* *}$ \\
\hline & {$[0.030]$} & [0.030] & {$[0.036]$} & {$[0.036]$} \\
\hline \multirow[t]{2}{*}{$\ln P_{o p}-\ln P_{o p} p_{t-1}$} & -0.3858 & $-0.4446^{*}$ & -0.0238 & -0.0269 \\
\hline & {$[0.236]$} & {$[0.258]$} & {$[0.280]$} & {$[0.285]$} \\
\hline \multirow[t]{2}{*}{ YoungSh $_{t}-$ YoungSh $_{t-1}$} & -0.0127 & & $-0.0120 *$ & \\
\hline & [0.009] & & {$[0.007]$} & \\
\hline \multirow[t]{2}{*}{ YoungDep $_{t}-$ YoungDep $_{-1}$} & & -0.0041 & & -0.0021 \\
\hline & & {$[0.004]$} & & [0.003] \\
\hline \multirow[t]{2}{*}{$O l d S h_{t}-O l d S h_{t-1}$} & -0.0127 & & -0.0260 & \\
\hline & [0.010] & & [0.021] & \\
\hline \multirow[t]{2}{*}{ OldDep $_{t}-$ OldDep $_{t-1}$} & & -0.0053 & & -0.0163 \\
\hline & & {$[0.005]$} & & [0.013] \\
\hline \multirow[t]{2}{*}{$\ln C a p_{t}-\operatorname{In} \operatorname{Cap}_{t-1}$} & $0.1829 * * *$ & $0.1889 * * *$ & $0.1053 * * *$ & $0.1056 * * *$ \\
\hline & {$[0.046]$} & [0.047] & [0.038] & {$[0.038]$} \\
\hline \multirow[t]{2}{*}{$h c_{t}-h c_{t-1}$} & $-0.4625 * * *$ & $-0.4544 * * *$ & -0.0909 & -0.0817 \\
\hline & [0.109] & [0.110] & [0.125] & [0.126] \\
\hline \multirow[t]{2}{*}{$\ln T t r d_{t}-\ln T t r d_{t-1}$} & -0.0340 & -0.0426 & $0.0889 *$ & $0.0892 *$ \\
\hline & {$[0.047]$} & {$[0.047]$} & {$[0.048]$} & [0.049] \\
\hline Observations & 265 & 265 & 879 & 879 \\
\hline Number of countries & 29 & 29 & 113 & 113 \\
\hline R-squared & 0.688 & 0.683 & 0.348 & 0.343 \\
\hline
\end{tabular}

Notes: 1. Panel estimation with country-specific and period-specific effects. 2 . Robust standard errors are in parentheses. 3. $* * *, * *$, and $*$ indicate the significance levels of 1,5 , and 10 percent, respectively.

Source: Authors' calculations 
Table 9: Negative Effects of population aging only in more aged countries

\begin{tabular}{|c|c|c|c|c|}
\hline \multirow[t]{3}{*}{ VARIABLES } & \multicolumn{2}{|c|}{ More aged countries } & \multicolumn{2}{|c|}{ Less aged countries } \\
\hline & OldSh > 6.32 & OldDep > 10.30 & OldSh $<6.32$ & OldDep $<10.30$ \\
\hline & $(1)$ & $(2)$ & (3) & (4) \\
\hline $\ln R G D P o_{t-1}$ & $\begin{array}{c}-0.3530 * * * \\
{[0.064]}\end{array}$ & $\begin{array}{c}-0.3517^{* * *} \\
{[0.064]}\end{array}$ & $\begin{array}{c}-0.1897 * * * \\
{[0.045]}\end{array}$ & $\begin{array}{c}-0.1868 * * * \\
{[0.045]}\end{array}$ \\
\hline $\ln P_{o p} p_{-1}$ & $\begin{array}{l}-0.1397 \\
{[0.128]}\end{array}$ & $\begin{array}{c}-0.1313 \\
{[0.128]}\end{array}$ & $\begin{array}{c}-0.2225 * * * \\
{[0.079]}\end{array}$ & $\begin{array}{c}-0.2168 * * * \\
{[0.079]}\end{array}$ \\
\hline YoungSh $_{t-1}$ & $\begin{array}{c}-0.0164 * * * \\
{[0.006]}\end{array}$ & & $\begin{array}{c}-0.0091^{* *} \\
{[0.004]}\end{array}$ & \\
\hline YoungDep $_{t-1}$ & & $\begin{array}{c}-0.0058 * * \\
{[0.003]}\end{array}$ & & $\begin{array}{c}-0.0027^{* *} \\
{[0.001]}\end{array}$ \\
\hline OldSh $_{t-1}$ & $\begin{array}{c}-0.0223^{* *} \\
{[0.010]}\end{array}$ & & $\begin{array}{l}-0.0145 \\
{[0.020]}\end{array}$ & \\
\hline OldDept-1 & & $\begin{array}{c}-0.0098 * \\
{[0.005]}\end{array}$ & & $\begin{array}{l}-0.0022 \\
{[0.010]}\end{array}$ \\
\hline $\ln \operatorname{Cap}_{t-1}$ & $\begin{array}{l}0.0624 \\
{[0.050]}\end{array}$ & $\begin{array}{l}0.0626 \\
{[0.048]}\end{array}$ & $\begin{array}{c}0.0476 * \\
{[0.028]}\end{array}$ & $\begin{array}{c}0.0473 * \\
{[0.028]}\end{array}$ \\
\hline$h c_{t-1}$ & $\begin{array}{l}0.0862 \\
{[0.081]}\end{array}$ & $\begin{array}{l}0.1039 \\
{[0.087]}\end{array}$ & $\begin{array}{c}-0.0548 \\
{[0.054]}\end{array}$ & $\begin{array}{l}-0.0483 \\
{[0.054]}\end{array}$ \\
\hline $\ln T t r d_{t-1}$ & $\begin{array}{l}0.0476 \\
{[0.069]}\end{array}$ & $\begin{array}{l}0.0456 \\
{[0.069]}\end{array}$ & $\begin{array}{c}0.0621^{*} \\
{[0.036]}\end{array}$ & $\begin{array}{c}0.0604 * \\
{[0.036]}\end{array}$ \\
\hline $\ln P_{o p}-\ln P_{o p} p_{t-1}$ & $\begin{array}{l}0.1046 \\
{[0.420]}\end{array}$ & $\begin{array}{l}0.0944 \\
{[0.418]}\end{array}$ & $\begin{array}{l}0.0040 \\
{[0.317]}\end{array}$ & $\begin{array}{l}0.0281 \\
{[0.322]}\end{array}$ \\
\hline YoungSh $_{t}-$ YoungSh $_{t-1}$ & $\begin{array}{c}-0.0237 * * * \\
{[0.008]}\end{array}$ & & $\begin{array}{c}-0.0073 \\
{[0.008]}\end{array}$ & \\
\hline YoungDep $_{t}-$ YoungDep $_{-1}$ & & $\begin{array}{c}-0.0091^{* *} \\
{[0.004]}\end{array}$ & & $\begin{array}{l}-0.0021 \\
{[0.003]}\end{array}$ \\
\hline$O l d S h_{t}-O l d S h_{t-1}$ & $\begin{array}{c}-0.0377 * * * \\
{[0.013]}\end{array}$ & & $\begin{array}{l}0.0068 \\
{[0.038]}\end{array}$ & \\
\hline OldDep $_{t}-$ OldDep $_{t-1}$ & & $\begin{array}{c}-0.0178 * * \\
{[0.007]}\end{array}$ & & $\begin{array}{l}0.0086 \\
{[0.021]}\end{array}$ \\
\hline $\ln C a p_{t}-\ln C a p_{t-1}$ & $\begin{array}{c}0.1074^{*} \\
{[0.055]}\end{array}$ & $\begin{array}{c}0.1119 * \\
{[0.058]}\end{array}$ & $\begin{array}{c}0.1103 * * * \\
{[0.042]}\end{array}$ & $\begin{array}{c}0.1097 * * \\
{[0.042]}\end{array}$ \\
\hline$h c_{t}-h c_{t-1}$ & $\begin{array}{l}0.0288 \\
{[0.199]}\end{array}$ & $\begin{array}{l}0.0451 \\
{[0.208]}\end{array}$ & $\begin{array}{l}-0.0906 \\
{[0.154]}\end{array}$ & $\begin{array}{l}-0.0947 \\
{[0.153]}\end{array}$ \\
\hline $\ln T t r d_{t}-\ln T t r d_{t-1}$ & $\begin{array}{l}-0.0546 \\
{[0.074]}\end{array}$ & $\begin{array}{l}-0.0567 \\
{[0.075]}\end{array}$ & $\begin{array}{c}0.0964 * * \\
{[0.048]}\end{array}$ & $\begin{array}{c}0.0953^{*} \\
{[0.048]}\end{array}$ \\
\hline Observations & 407 & 407 & 737 & 737 \\
\hline Number of countries & 67 & 67 & 96 & 96 \\
\hline R-squared & 0.529 & 0.519 & 0.330 & 0.327 \\
\hline
\end{tabular}

Notes: 1. Panel estimation with country-specific and period-specific effects. 2. Robust standard errors are in parentheses. $3 . * * *, * *$, and $*$ indicate the significance levels of 1,5 , and 10 percent, respectively.

Source: Authors' calculations 
Appendix Table 1: Sources/Definitions of Variables

\begin{tabular}{|c|c|c|}
\hline Variables & Description and construction & Data Source \\
\hline Real GDP & $\begin{array}{l}\text { Per Capita Output-side real GDP at chained PPPs (in } \\
\text { mil. 2011US\$) }\end{array}$ & Penn World Table 9.0 \\
\hline Population & Total Population & $\begin{array}{l}\text { World Bank's World } \\
\text { Development Indicators }\end{array}$ \\
\hline $\begin{array}{l}\text { Working Age } \\
\text { Population Share }\end{array}$ & Population ages $15-64$ ( $\%$ of total population) & $\begin{array}{l}\text { World Bank's World } \\
\text { Development Indicators }\end{array}$ \\
\hline $\begin{array}{l}\text { Young Population } \\
\text { Share }\end{array}$ & Population ages $0-14$ ( $\%$ of total population) & $\begin{array}{l}\text { World Bank's World } \\
\text { Development Indicators }\end{array}$ \\
\hline Old Population Share & Population ages 65 and above ( $\%$ of total population) & $\begin{array}{l}\text { World Bank's World } \\
\text { Development Indicators }\end{array}$ \\
\hline $\begin{array}{l}\text { Young Age } \\
\text { Dependency Ratio }\end{array}$ & $\begin{array}{l}\text { Ratio of people younger than } 15 \text { to the working age } \\
\text { population }\end{array}$ & $\begin{array}{l}\text { World Bank's World } \\
\text { Development Indicators }\end{array}$ \\
\hline $\begin{array}{l}\text { Old Age Dependency } \\
\text { Ratio }\end{array}$ & $\begin{array}{l}\text { Ratio of people older than } 64 \text { to the working age } \\
\text { population }\end{array}$ & $\begin{array}{l}\text { World Bank's World } \\
\text { Development Indicators }\end{array}$ \\
\hline Capital Stock & Capital Stock at current PPPs (in mil. 2011 US\$) & Penn World Table 9.0 \\
\hline Human Capital & Human Capital Index & Penn World Table 9.0 \\
\hline Trade Share & $\%$ of GDP & $\begin{array}{l}\text { World Bank's World } \\
\text { Development Indicators }\end{array}$ \\
\hline
\end{tabular}

